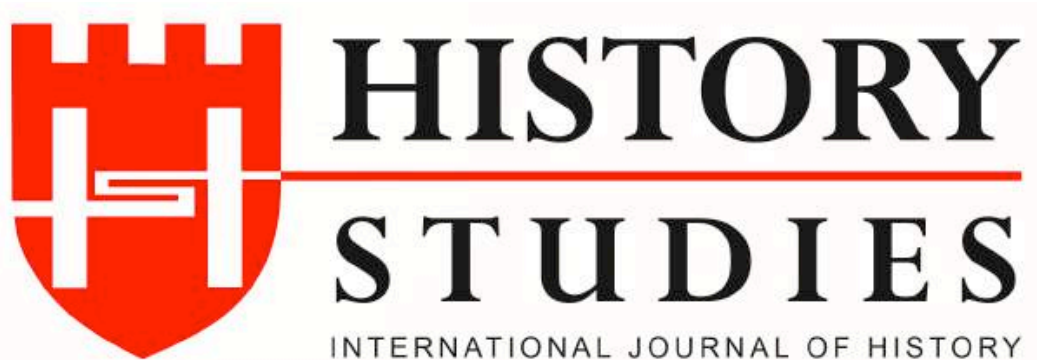

ISSN: 13094173 (Online) 1309 - 4688 (Print)

Volume 12 Issue 1, February 2020

DOI Number: 10.9737/hist.2020.820

Araştırma Makalesi

Makalenin Geliş Tarihi: 31.10.2019 Kabul Tarihi: 13.01.2020

Atıf Künyesi: Ayşegül Bekmez, "Kırşehir Melik Gazi Türbesi Üzerinden Yeni Bir Değerlendirme”, History Studies, 12/1, Şubat 2020, s. 55-85.

\title{
Kırşehir Melik Gazi Türbesi Üzerinden Yeni Bir Değerlendirme
}

\author{
A New Evaluation Through Kırşehir Melik Gazi Tomb
}

\author{
Arş. Gör. Ayşegül Bekmez \\ ORCID No: 0000-0001-6121-1045 \\ Van Yüzüncü Y1l Üniversitesi
}

$\ddot{O} z$

Kırşehir merkezde bir park içinde bulunan Melik Gazi Türbesi, Anadolu Selçuklu mimarisinde cephe düzenlemesi ve süslemesi ile özel bir yere sahiptir. Anadolu Selçuklu siyasetinin en karmaşık olduğu süreçte inşa edilen eser, kitâbesi, mimari ve süsleme özellikleriyle dönem hakkında ipuçları vermektedir. Türbe bugüne kadar birçok yayında cephe düzeni ve süslemeleri açısından incelenmiştir. Bu çalışmanın amacı, yapının dikkat çeken mimari özelliklerinin yanında kitâbesi ve süsleme özellikleri üzerinde yoğunlaşarak yeni değerlendirmeler de bulunmaktadır. Türbenin kitâbesi bugüne kadarki yayınlarda ikinci planda kalmış ve yeterince ele alınmamıştır. İnceleme iki farklı başlıkla türbeyi değerlendirmektedir. İlk başlıkta türbe inşa kitâbesi incelenmektedir. Yapılan çalışma ile kîtâbe içeriği daha ayrıntılı olarak ele alınırken; yapı ile ilgili yeni değerlendirmeler için de kapı aralanmaktadır. İkinci başlıkta ise türbe ile bağlantılı olduğu düşünülen türbenin $50 \mathrm{~m}$. kuzeyindeki Lale Cami ve bir zamanlar türbenin yanında bulunan Melik Gazi Medresesi ile türbe birlikte değerlendirilmektedir. Bu üç yapının birlikte ele alınması ile bir yapı topluluğunun parçaları olabileceklerine dair sorulara cevap aranmaya çalışılmaktadır. Araştırmanın sonucunda Melik Gazi Türbesi'nin inşa tarihi ve bânîsi ile ilgili yeni bulgular ve çevresindeki Lale Cami ve Melik Gazi Medresesi arasındaki bağlantılar hakkında yeni değerlendirmelerde bulunulmaktadır. Ayrıca Kırşehir'de Türk döneminin en önemli imar faaliyetlerine imza atan Melik Muzafferüddin'in şehre yaptığı katkılar da irdelenmektedir.

Anahtar Kelimeler: Kırşehir, Melik Gazi Türbesi, Melik Gazi Medresesi, Lale Cami, Kitabe, Yapı Topluluğu.

\section{Abstract}

Melik Gazi Tomb, which is located in a park in Kırşehir center holds a special place in Anatolian Seljuk architecture due to its façade arrangement and decoration. Built in the most chaotic period of Anatolian Seljuk political landscape, the body of work gives clues about the period with its epitaph, decoration and architectural features. To date, the tomb has been examined in many publications in terms of façade arrangement and decoration. The purpose of this study is to make new evaluations by focusing on its epitaph and decoration features in addition to its striking architectural features. Epitaph of the tomb has stayed in the background in publications to date and it has not been sufficiently discussed. The research evaluates the tomb under two different titles. In the first title, inscription on the tomb was evaluated. With this study, while the context of the inscription is 
discussed in more detail; it cracks the door open for new evaluations regarding the structure. In the second title, Lale Mosque which is situated only 50 meter from the tomb and is thought to be related with the tomb and Melik Gazi Madrasah which was once next to the tomb are evaluated together with the tomb. With discussing these three structures together, it is tried to seek for an answer to question such as whether they are part of a set of buildings. At the end of this research, new findings have been achieved about the builder of Melik Gazi Tomb and when was it built, and new evaluations have been made regarding the connection between Lale Mosque and Melik Gazi Madrasah. Moreover, contributions of Melik Muzafferüddin who involved in the most important construction activities in Kırşehir to the city were examined as well.

Keywords: Kırşehir, Melik Gazi Tomb, Melik Gazi Madrasah, Lale Mosque, İnscription, Bulding Complex.

\section{Giriş}

Melik Gazi Türbesi, Kırşehir merkezde Yenice Mahallesinde bir park içinde bulunmaktadır. Türbe, giriş lento taşı üzerinde bulunan inşa kîtâbesinden anlaşıldığı kadarıyla Melik Muzafferüddin için, onun hareminden bir kadın tarafından yaptırılmıştır. Metinde tarih bilgisine yer verilmemiştir. Yapı, plan ve süsleme özellikleri dikkate alınarak farklı sanat tarihçiler tarafından 13. yüzyılın ikinci yarısı ya da 1260-1265 yıllarına tarihlendirilmektedir. ${ }^{1}$ Mehmet Emin Kılıç diğer görüşlerden farklı olarak türbe kîtâbesinin aslında yanındaki medreseye ait olduğu, 1890'da yıkılan medrese kîtâbesinin türbeye taşınmış olabileceğini ve türbenin 1260-1265 yılları arasında inşa edilmiş olabileceğini iddia etmektedir. ${ }^{2}$

Türbe, sekizgen gövdeli, kare kaideli, iki katlı ve içten kubbe dıştan konik bir külahla örtülüdür. İlk kat, mezar odası, ikinci kat mescittir. Sekizgen gövde yukarı doğru daralarak silindirik bir forma dönüşmektedir. Türbede kuzey, doğu ve güneybatı yönlerinde üç pencere bulunmaktadır. Kaide kısmındaki pahlar, gövdedeki silmeler ve külah türbeye bir çadır görünümü vermektedir. Kuzey cephedeki köşe pahları üçgen şekilde olmayıp yüksek kare kaideli olarak bırakılmıştır. Bu kısmın özgününde nasıl olduğu tartışmalıdır. Aynı cephede yüzeydeki bazı taşların onarım sırasında değiştirildiği anlaşılmaktadır. Ancak yapılan incelemelerde bu cephenin makalenin ilerleyen bölümlerinde açıklanan nedenlerle özgününde pahlanmamış olduğu düşünülmektedir. Kuzeybatı köşesindeki kare kaidenin batı yönünde bir duvarın varlığ izlerden anlaşılmaktadır.(Fotoğraf:4)

\footnotetext{
${ }^{1}$ Orhan Cezmi Tuncer, Anadolu Kümbetleri I Selçuklu Dönem, Güven Matbaası, Ankara, 1986, s. 174; Hakkı Önkal, Anadolu Selçuklu Türbeleri, Atatürk Kültür Merkezi Yayınları, Ankara, 2015,s. 112.

${ }^{2}$ Mehmet Emin Kılıç, Selçuklu Döneminde Kırşehir, XIII-XIV. Yüzyıllarda Kırşehir ve Yöresinin Siyasi, Sosyal, Kültürel ve Dini Tarihi, Basım Yeri ve Yılı Bulunmuyor, s. 247.
} 

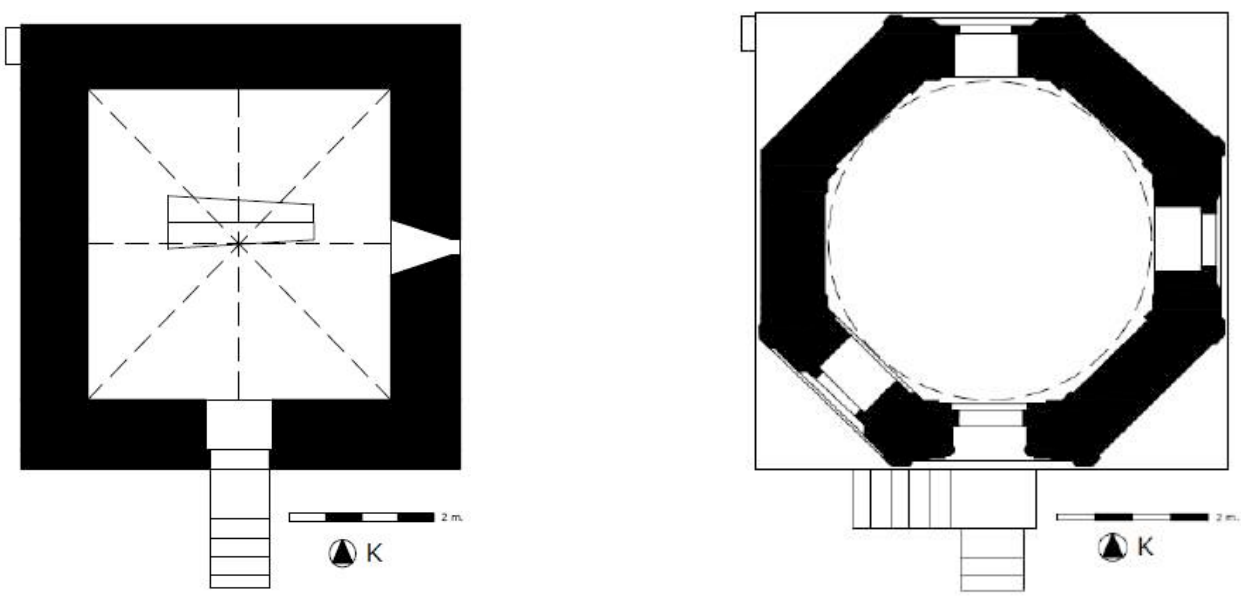

Plan 1: Melik Gazi Türbesi İlk ve İkinci Kat Planları (Toy, 2010, s. 76)

Cenazelik katı, kare planlı ve çapraz tonozla örtülüdür. Türbe zamanla oluşan kot farkı nedeniyle yol zemininden 1 metre kadar aşağıda kalmıştır. İkinci kata giriş, güney cephede bulunan taçkapı ile sağlanmaktadır. Girişe tek yönlü bir merdivenle çıkılmaktadır. Yapının kaide kısmının tamamen toprak altında kaldığ 1 ve yapılan kazı çalışmalarıyla mezar odası kapısının ortaya çıkarıldığı bilinmektedir. ${ }^{3}$ Orijinal giriş bugün açılan kapı ile aynı yönde bulunmaktadır. Oluşan kot farkı nedeniyle mezar odası aşağıda kalmış bu nedenle mezar odasına güney cephede merdiven hizasında zemine açılmış bir kapı ile girilmektedir. Ancak son arazi çalışmasında zeminin toprakla doldurulması nedeniyle kapının kapandığı görülmüştür. $\mathrm{Bu}$ kat doğu yönünde bulunan bir adet mazgal pencere ile aydınlatılmıştır. İçerisinde sonradan eklenmiş bir sanduka yer almaktadır. ${ }^{4}$

Mescit katı, iç mekânı sekizgen planlıdır. Sekizgen gövdenin her bir kenarında kubbeye kadar uzanan sivri kemer şeklinde düzenlenmiş silmeler bulunmaktadır. Silmelerin bitimiyle gövde silindiriğe dönüşmekte ve kubbe ile örtülmektedir. Türbenin bu kısmı niş içine alınmış üç pencere ile aydınlatılmıştır. Pencereler kuzey, doğu ve güney batı cephelerinde yer almaktadır. Bu bölümde mihrap ya da sanduka bulunmamaktadır. Güney cephede açılan giriş, mescit katında mihrap yapılmamasına neden olmuştur. Dönem türbelerinde bir zorunluluk olmamakla birlikte güney cepheye genellikle mihrap yerleştirilmektedir.

Türbede süslemeler gövdede yoğunlaşmaktadır. Güneydeki taçkapı, sekizgen gövdenin köşe silmeleri ve mescit katı duvar yüzeylerindeki silmeler üzerindeki süslemelerle yap1 hareketlendirilmiştir. Türbenin cephe düzenlenmesinde en dikkat çekici unsur sekizgen gövdenin her kenarının külahla bütünlük oluşturacak şekilde üçgen silmelerle kuşatılmasıdır. Sekizgen gövdenin kenarları iç mekânda da üç şeritli, sivri kemerli silmelerle hareketlendirilmiştir. Üç cepheden açılan pencereler de dıştan sivri kemerli silmelerle çevrelenmiştir. Dışta sekizgen gövdenin her köşesinde silme yüzeylerinde birbirlerini çapraz olarak kesen geçmelerin oluşturduğu kompozisyon yer almaktadır. Cephe süslemesinin en

${ }^{3}$ Ali Sami Ülgen,'Kırşehir'de Türk Eserleri', Vakıflar Dergisi, S 2,Ankara, 1942, s. 257.

${ }^{4}$ Agm. s. 257; Hakk1 Önkal, age. s. 110. 
yoğun olduğu bölüm taçkapıdır. Üç sıra mukarnaslı taçkapı, dört sivri kemerle kademeli olarak kuşatılmıştır. En diş ve ikinci bordür palmet ve rumilerle bezenmiştir. İkinci bordürde palmeti oluşturan rumiler kenarlarda kıvrılmışlardır. Taçkapı kavsarasının oturduğu sütuncelerin gövdeleri geometrik, başlıkları ise dairesel bir düzendedir. Süslemeler alçak kabartma ve yivli oyma teknikleri ile işlenmiştir.(Fotoğraf:8-15)

Yapının geneli sarı kalker taşı ile inşa edilmişken; taçkapıda mermer kullanılmıştır. Mermer malzeme giriş cephesinde sadece gövde kısmında yer almaktadır. Mermerin güneyde taçkapı etrafında ve külahın hemen altındaki üçgen kuşakta kullanılması, diğer kısımlar da ise sarı kalkere yer verilmesi, ayrıca taçkapıda süslemenin mermer nedeniyle daha belirgin hale gelmesini sağlamıştır. Bu kullanım türbenin girişini vurgulamaktadır. Muhtemelen türbenin tasarımı sırasında bu etki hesaplanmış ve tasarım bu şekilde tamamlanmıştır. (Fotoğraf:8-9)

\section{Kîtâbe İncelemesi}

Bu bölümde yapının tarihlendirilmesi ve bânîsi ile ilgili bilgiler barındırdığı düşünülen, kîtâbesi ayrıntılı bir biçimde ele alınmakta, kîtâbenin kaynaklarda nasıl okunduğu değerlendirilmektedir. Melik Gazi Türbesi'nin kitâbesinde yer alan bazı ifadeler yapı ile ilgili farklı varsayımları akla getirmektedir. Lento taşı üzerindeki kitâbe şu şekildedir:(Fotoğraf:6)

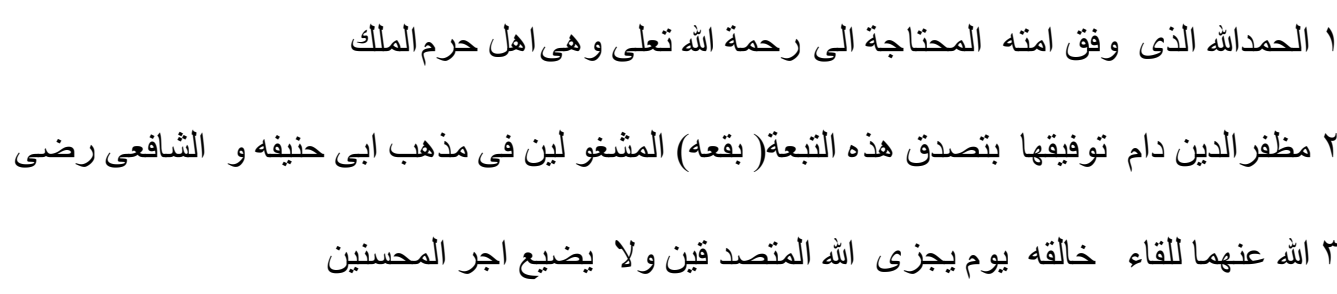

OKUNUŞU:1 Elhamdülillâh vefk emetehu el- muhtâcetu ilâ rahmetellâhi teâla vey 'î ehl-u harame el-melik

2 Muzafferüddin dâme tuveffikuha bî tasadduk haza el-tebiâti el-muşğulin fî mezhebi ebi-Hanife ve'l Şâfî radiy

3 Allâhu anhümâ lilkaî halikehu yevme yecziyellâhu mütesaddikîn vela yediul ecru’lmuhsinin.

ANLAMI: Allah'a hamd olsun ki, Melik Muzafferü'd-dinin harem ehlinden Allah'in rahmetine muhtaç kulu (cariyesi) (tevfiki daim olsun), Cenab-1 Hakkın tasadduk edenleri mükâfatlandırdığı ve ihsan sahiplerinin ecrini zayi etmediği bir günde Halıkince yaklaşmak dileğiyle Ebu Hanife ve Şafii (Allah onlardan razı olsun) mezhebiyle meşgul olanlar için (Melik Muzafferü'd-din'in) tasaddukta bulunma arzusunu gerçekleştirmekte muvaffak kıldı. ${ }^{5}$

\footnotetext{
${ }^{5}$ Halim Baki Kunter, 'Kitâbelerimiz I', Vakıflar Dergisi S.2,Ankara, 1942, s. 435.
}

\section{History Studies}


Yapının kîtâbesi bugüne kadar beş kez yayınlanmıştır. Yapı ile ilgili diğer yayınlar bu kaynaklardan alıntı yapmışlardır. Kitabe, ilk kez 1938 tarihi Kırşehir Tarihi isimli kitapta C. H. Tarım tarafından yayınlanmıştır. ${ }^{6}$ Tarım, yayında kîtâbenin Arapça harfle yazılışını ve Türkçe anlamını paylaşmıştır. Kîtâbe genel olarak sonradan yayınlanan kaynaklardaki okunuşlara benzemekle birlikte bir kelimenin okunuşu ile diğerlerinden ayrılmaktadır. Bu okuma, kîtâbe içeriğginin anlamı değiştirmesi bakımından önemlidir. Yayında ikinci satırda هذاه 'den sonraki kelime 'بقعه، 'olarak okunmuştur. Tarım, kîtâbenin tercümesini verirken yapıdan darül-ilim olarak bahsetmektedir. Buk'a kelimesi Arapça parsel, arazi parçası, büyük bina, anıt anlamlarına gelmektedir. (Fotoğraf:7)

Türbe kîtâbesi, 1942'de H. B. Kunter tarafından Vakıflar Dergisinde tekrar yayınlamıştır. Kunter'in yayını daha sonraki birçok kaynakta da kullanılmıştır. Kunter, Tarım'dan farklı olarak ikinci satırda هذاه 'den sonraki kelimeyi 'تبعة' olarak okunmuştur. Te'ba kelimesi Arapça'da uymak, tabi olmak, izlemek, takip etmek, araştırmak, hizmetçi, bağlı, ek, ilave gibi anlamlara gelmektedir. ${ }^{8}$ Dönem kîtâbeleri incelendiğinde bu kelimenin kullanımına rastlanmamıştır. Eğer kelime doğru okunmuşsa kîtâbede ek bina anlamında kullanılmış olabileceği düşünülmektedir.

1948'de Cevat Hakkı Tarım 'Tarihte Kırşehri ve Gülşehri ve Babailer-Ahiler-Bektaşiler' isimli kitabında kîtâbeyi tekrar yayınlamış ancak bu kez بقبع، kelarak okumuştur. Tarım'ın kitabında bu değişikliğe neden gidildiği açıklanmamaktadır. Ayrıca daha önceki yayınında değindiği türbenin aynı zamanda bir darül-ilim olduğu açıklaması bu yayında bulunmamaktadır. ${ }^{9}$

Hakkı Önkal 'Anadolu Selçuklu Türbeleri' isimli yayınının, 1996 ve 2015 yıllarındaki baskılarında kîtâbeyi yayınlamıştır. Önkal birkaç değişiklik dışında Kunter'in okumasına bağlı kalmıştır. Önkal da هذاهkelimesinden sonraki kelime 'تبعة olarak okunmuştur. Önkal ayrıca kîtâbenin Selçuklu kîtâbelerinden farklı bir üslupta yazıldığından ve imla hatalarının bulunduğundan bahsetmektedir. ${ }^{10}$

Mehmet Emin Kılıç'ın basım yılı bulunmayan "Selçuklu Döneminde Kırşehir XIII-XIV. Yüzylllarda Kırşehir ve Yöresinin Siyasi, Sosyal, Kültürel ve Dini Tarihi” isimli kitabında da türbeden bahsedilmiş ve kîtâbesine yer verilmiştir. ${ }^{11}$ Kılıç da هذاهkelimesinden sonraki kelime ' تبعة olarak okumuştur. Yayında kîtabe okunmasında Kunter'e bağlı kalınmış ancak Türkçe anlamı farklı bir şekilde yapılmıştır. Kîtâbenin tercümesi "Muzafferüddin harem-sarayı ehli, Tanrı rahmetine muhtaç câriyesi, Tevfik inayet buyuran Allah'a hamd, O Cenab-ı Hakkın tasadduk edenleri mükâfatlandırdı̆̆ ve ihsan sahiplerinin ecrini zâyi etmediği günde,

\footnotetext{
${ }^{6}$ Cevat Hakkı Tarım, Kırşehir Tarihi, Kırşehir Vilayet Matbaası, Kırşehir, 1938,s. 51.

${ }^{7}$ Halim Baki Kunter, agm, s. 435.

${ }^{8}$ Serdar Mutçalı, Arapça-Türkçe Sözlük, Dağarcık, İstanbul,1995,s. 83.

${ }^{9}$ Cevat Hakkı Tarım, Tarihte Kırşehri ve Gülşehri ve Babailer-Ahiler-Bektaşiler, Yeniçağ Matbaası, İstanbul,1948, s. $39-40$.

${ }^{10}$ Hakkı Önkal, age, s.112.

${ }^{11}$ Mehmet Emin K1lıç, Selçuklu Döneminde Kırşehir, XIII-XIV. Yüzyıllarda Kırşehir ve Yöresinin Siyasi, Sosyal, Kültürel ve Dini Tarihi, Basım Yeri ve Yılı Bulunmuyor, s. 247.
} 
Hâlık'ının huzuruna çıkardı̆̆ı günü tahattur ederek, Eb̂̂ Hanife ve Şâfii(Allah onlardan razı olsun) mezhebiyle iştigal edenler için burasını yaptırdı. Tevfiki daim olsun." şeklindedir.

Anadolu Selçuklu dönemi inşa kîtâbeleri incelendiğinde, çoğunluğunda belirli bir standardın kullanıldığı anlaşılmaktadır. Arapça yazılan kîtâbelerde, yapım kipi, işlev bilgisi, hükümdarlık vurgusu, bânî adı ve tarih yer almaktadır. ${ }^{12}$ Yapım kipinden kasıt, yapının yeni inşa edildiği mi yoksa tamir ya da yenilenme mi geçirdiği bilgisidir. İşlev bilgisi yapının ne amaçla yapıldığı ile ilgili bilgiler içermektedir. Hükümdarlık vurgusu yer alan kısımda dönem hakkında bilgiler yer almaktadır. Diğer satırlarda ise, yapıların bânîleri ve bazen de bina eminleri ve usta isimleri bulunmakta; son satırda ise, yazı ile inşa tarihi yer almaktadır.

Kîtâbeyi bu bilgiler ve farklı okunuşlar ile tekrar satır satır ele almak gerekirse;

$$
\text { ا الحمداله الذى وفق امته المحتاجة الى رحمة الله تعالى وهى اهل حرم الملك }
$$

İlk satırda yapının bânîsi olduğu düşünülen kişinin kimliği ile ilgili bilgeler yer almaktadır. Devamı ikinci satırda kalan Allah'a hamd olsun ki Melik Muzafferüddin'in harem ehlinden Allah'ın rahmetine muhtaç kulu ibareleri, yapının bir kadın tarafından yaptırıldığını göstermektedir. Özellikle el muhtace sıfatının sonundaki "e" cümlede bir kadından bahsedildiğini ortaya koymaktadır. İncelediğimiz çoğu inşa kitâbesinde, genellikle bu kısımda isim yerine lakaplar kullanıldığı anlaşılmaktadır. El âlime, el abide, el zahide, el sahibe, el hatun, el melike, el kebire, el adile, el cariye, el zayife, el muhtace, el saide, el şehide, el sit, el masuma gibi sıfatlar kadın bânîler için sıklıkla kullanılan ifadelerdir. Melik Gazi Türbesini yaptıran hatun için bu sıfatlardan sadece el muhtace kullanılmıştır. İncelediğimiz dönem kîtâbelerinde hanedan mensubu bânî hatunların inşa kîtâbeleri ile hanedanla ilişkisi olmayan bânî hatunların inşa kîtâbeleri arasında bir fark bulunmaktadır. Hanedan mensubu kadınların inşa kitâbelerinde birçok övücü ibare yer almaktadır. Safvet-ül dünya ved-din, ismet-ül dünya ved-din, radiyetüd dünya ved-din, safvet'tül islam vel müslimin, kerime el dünya ved-din, muazzameti safvet-i dünya ved-din, azameti'd dünya ved-din gibi sıfatları sadece hanedanla ilişkisi bulunan kadın yapılarının kitâbelerinde görülmektedir. Melik Gazi Türbesi kitâbesinde bu ifadelerin hiçbiri yer almamaktadır. Bânî hatun için sadece el muhtace sıfatı kullanılmıştır. $\mathrm{Bu}$ durumda türbeyi Melik Muzafferüddin'in II.Giyasettin Keyhüsrev'le evlenen kızının yaptırmadığı anlaşılmaktadır. Kitâbeyi inceleyen A. Tüfekçioğlu ${ }^{13}$, ilk satırda geçen 'emete' ifadesinin bir isim de olabileceğini söylemektedir. Emete kelimesi etimolojik açıdan incelendiğinde farklı sonuçlar ortaya çıkmaktadır. Emete'nin Türkçe karşılığı hala, kız kardeştir. ${ }^{14} \mathrm{Bu}$ kelime Orta Anadolu'da özellikle Melik Muzafferüddin ve ailesinin geldiği Şebinkarahisar'da hala yerine yaygın olarak kullanılmaktadır. ${ }^{15}$ Emete özel isim olarak da kullanılmaktadır. Emete'nin kîtâbenin yazıldığı dil olan Arapça'daki karşılığı millet, topluluk

\footnotetext{
${ }^{12}$ Kemal Özkurt-Abdülhamit Tüfekçioğlu," Türk-İslam Sanatında Kitabeler”, Türkiye Araştırmaları Literatür Dergisi, C. 7, S. 14, 2009, s.278; Hakk1 Önkal, 'Epigrafik Metinlerin Deşifresinde Takip Edilebilecek Usul Hakkında Düşünceler', Prof. Dr. Selçuk Mülayim Armağanı: Sanat Tarihi Araştırmaları(Edt. A.Doğanay), Lale Yayınevi, İstanbul 2016, s. 29.

13 Abdülhamit Tüfekçioğlu, Kișisel Görüșme, 2016.

${ }^{14}$ Derleme Sözlüğü (Türkiye Türkçesi Ağızları Sözlüğü), Türk Dil Kurumu, C. 5, Ankara Üniversitesi Basımevi Ankara,1993, s.1731.

${ }^{15}$ Age, s. 1731.
} 
kavimdir. ${ }^{16}$ Emete'nin kitâbede geçtiği cümle yapısı incelendiğinde; kelimenin cümlenin öznesi olduğu anlaşılmaktadır. Özne olan Emete muhtemelen yapının bânisi olan kadını tanımlamaktadır. Sözcüğün anlamı için yapılan açıklamaların tamamı kadınlar için kullanıldığını ortaya koymaktadır. Özellikle Orta Anadolu'da Emete isminin kadınlar için verildiği düşünülünce bâninin isminin Emete Hatun olabileceği mümkün görülmektedir. Benzer bir şekilde aynı dönemde başka bir kîtâbede de hatun ibaresi kullanılmadan sadece isme yer verilmiştir. Develi Ulu Cami kitâbesinde yapının bânîlerinden biri olan Sivasti Hatun için 'el muhtace ila rahmet-illah-i ve rizvane-hu Sivasti' ifadesi kullanılmıştır. ${ }^{17}$

Kitâbenin ilk satırında dönem örneklerinde bulunan 'amera', 'imare' 'inşa' 'bina' gibi yapım kiplerini içeren ifadelerin yer almadığı görülmektedir. Bu durum Kırşehir Melik Gazi Türbesi'nin bir yapının bünyesinde bulunduğuna işaret etmektedir. O. C. Tuncer'in de belirttiği türbenin kuzeybatı-kuzeydoğu köşelerindeki duvar izleri ve kîtâbesindeki belirsizlikler bunu desteklemektedir. Eğer yapı tek başına tasarlanmış olsa idi, kîtâbede bu kadar belirsizlik bulunmaması gerekirdi. Herhangi bir yap1 bünyesinde bulunan türbelerin çoğunluğunun(Kayseri Hunat Hatun Türbesi, Kayseri Gevher Nesibe Türbesi, Erzurum Çifte Minareli Medrese Türbesi kîtâbe siz olması ya da çok az bilgi içermesinin nedeni zaten ana yapı da var olan bilgilerin tekrar edilmek istenmemesi olabilir.

$$
\text { r مظفر الدين دام توفيقها بتصدق هذه التبعة المشغلين فى مذهب ابى حنيفه و الثاثا فعى رضى }
$$

İkinci satır, birinci satır sonunda Melik ile biten kelimenin devamında Muzaffrüddin ismi ile başlamaktadır. Bundan sonrası sadakasını daim kılmak için şeklinde devam edip haze yani bu kelimesine gelinmektedir. Kîtâbelerde 'haze' kelimesinden sonra genellikle bir yap1 türü yazılmaktadır. Kaynaklarda farklı okumaların bulunduğu haze 'den sonraki kelime muhtemelen yapının işlevi ile ilgili bir ifadedir. Kelimenin hangi harfle başladığı tartışmalıdır. İlk yayında bu kelime ' $b$ ' harfi ile başlatılırken, diğer yayınlarda ' $t$ ' ile başlatılmıştır. Kîtâbe dikkatli incelendiğinde ' $b$ ' harfinin daha önde olduğu anlaşılmaktadır. İkinci sıradaki harf de kaynaklarda farklı okunmuştur. Cevat Hakkı Tarım, ilk yayınında bu harfi 'k' olarak okumuş, daha sonra yayınlarda ise ' $t$ ' olarak okunmuştur. Bu durum ilk okunuştan sonra kîtâbenin herhangi bir tahribata uğrayıp uğramadığı sorusunu akla getirmektedir. Ancak yapılan incelemede de kîtâbede herhangi bir tahribat izine rastlanmamıştır. Kelimenin sonundaki iki harf bütün yayınlarda aynı okunmuştur. Fakat baştan iki harfin farklı okunuşları cümlenin ve dolayısıyla kîtâbenin bütün anlamını değiştirmektedir. Şayet bu kelime 'buk'a' olarak okunursa kîtâbenin anlam bütünlüğü de sağlanmaktadır. Buk’a Anadolu Selçuklu çağında mimari yapılar için kullanılan bir terimdir. Selçuklu döneminde yapılmış Tokat Halef Sultan Tekkesi, Harput Arap Baba Mescidi inşa kîtâbe sinde ve Ahlat Şeyh Necmettin Türbesi ve Erzurum Yakutiye Medresesi vakfiye kîtâbelerinde buk'a kelimesi geçmektedir. Kelimenin 'teb'a' olarak okunması ise kîtâbede bir anlam kaymasına neden olmaktadır. 'Teb'a' kelimesinin

\footnotetext{
${ }^{16}$ Serdar Mutçalı, age, s.24.

${ }^{17}$ Kerim Türkmen, 'Kayseri’de İmar Faaliyetine Katkıda Bulunan Hanımlar', II. Uluslararası Ahilik Sempozyumu Ahilikte Kadının Yeri, Kayseri, s. 33.
} 
anlamlarından biri de ek ilavedir. Kelime kîtâbe de bu anlamıyla ek bina, anlamında kullanılmış olabilir. Ancak dönem kîtâbelerinde bu kullanıma rastlanmamaktadır.

İkinci satırın son kısmında bir türbe kîtâbesinden farklı olarak hanifi ve şafii mezhepleri vurgulanmaktadır. Mezhep vurgusu yapı kitâbesinin türbe için değil medrese için yazılmış olabileceğini düşündürmektedir. Türbe muhtemelen karşısındaki medresenin parçası idi. Kîtâbedeki Şafi ve Hanefi mezhep vurgusu türbe kitâbelerinde rastlanmamakla birlikte medrese kîtâbe ve vakfiyelerinde bu ifadeler yer almaktadır. Konya Sırçalı Medresesi kîtâbe sinde benzer şekilde Hanefi mezhebi, Diyarbakır Mesudiye Medresesi kîtâbesinde ise dört mezhep vurgulanmıştır. Amasya Hilafet Gazi Medresesi, Konya Altun Aba Medresesi, Konya Karatay Medresesi, Sivas Gök Medrese vakfiyelerinde de benzer ifadeler kullanılmıştır. Kîtâbe deki bu uygulama ile ilgili diğer bir görüş ise türbenin üst katının bir darülalim olduğu ve bu nedenle kîtâbesinde mezhep vurgusunun yapıldığı yönündedir. ${ }^{18}$ Ancak Anadolu'da Selçuklu döneminde iki katlı birçok türbe yapılmıştır. Bu türbelerin üst katları genellikle mihraplı bir şekilde tasarlanmıştır. Mescit katı olarak adlandırılan üst katın kullanımı ile ilgili farklı görüşler bulunmakla birlikte medrese ya da eğitim amaçlı kullanıldığına dair herhangi bir belge ya da bilgiye rastlanmamaktadır. Ayrıca ikinci satırda geçen 'tasadduk' kelimesi de sadaka ile benzer anlamdadır ve vakıf kayıtlarında sıklıkla karşımıza çıkmaktadır.

$$
\text { r الله عنهما للقاء خالقه يوم يمحبزى الله المتصد قين ولا يضيع اجر المحسنين }
$$

Üçüncü ve son satır bütün kaynaklarda benzer şekilde yayınlanmıştır. Son satır baştaki iki satırın tamamlayıcısı şeklindedir. Satırda genel olarak Cenab-ı Hakkın tasadduk edenleri mükâfatlandırdiğı ve ihsan sahiplerinin ecrini zayi etmediği bir günde Halıkince yaklaşmak dileğiyle ifadeleri yer almaktadır.

Yapının inşa kîtâbesinde bulunan ifadeler ve bunların yapı ile ilgili düşündürdükleri dışında kîtâbede bulunmayan ifadelerden yola çıkılarak da bazı yorumlamalara gidilebilmektedir. Yapının işlevinin belirtildiği 'türbe', 'meşhed', 'kabr' gibi tanımlar Melik Gazi Türbe kitâbesinde yer almamaktadır. Ayrıca türbe kîtâbelerinde sıklıkla yer alan Allah rahmet eylesin, merhum gibi ölümle ilgili tabirler de kîtâbe metninde bulunmamaktadır. Bu durum kîtâbenin başka bir yapıdan getirildiğini ya da medresenin başka bir birimine ait olabileceği fikrini güçlendirmektedir. Kırşehir'de Kapıcı Cami ve Alâeddin Cami gibi yapılarda de başka yapıların kîtâbeleri bulunmaktadır. Şehirde yıkılan yapının parçalarının başka yapılarda kullanılması yaygındır. Melik Gazi Türbesi içinde benzer bir durum düşünülebilir. Ancak türbe üzerinde kîtâbenin sonradan yerleştirildiğini gösteren herhangi bir iz veya yapıya müdahalede bulunulduğunu belirten herhangi bir bilgi rastlanmamıştır. Aynı şekilde hükümdarlık vurgusunun yapıldığı ve dönemin sultanının benzer ifadelerle yüceltildiği kîtâbe bölümü Melik Gazi Türbesi'nde bulunmamaktadır. Kîtâbede yer almayan bu bölüm türbenin tarihlendirmesini bir kez daha güçleştirmektedir. Melik Muzafferüddin'in yaptırdığı medrese, inşa kîtâbesine göre II. İzzettin Keykavus döneminde inşa edilmiştir. Türbe bu dönemden sonra yapılmış olmalıdır. Genellikle inşa kitâbelerinin son kısmında yer alan tarih kısmı da Melik Gazi Türbesi'nde bulunmamaktadır. Yapıyı tarihlendirirken 1246 tarihli Melik Muzafferüddin'in

\footnotetext{
${ }^{18}$ Cevat Hakkı Tarım, Kırşehir Tarihi, s.52.
} 
yaptırdığı medrese dikkate alınmaktadır. 1272 tarihli Caca Bey Vakfiyesinde Melik Muzafferüddin'in ile bağlantılı bir kişinin şahit olarak adının yazması ${ }^{19}$ Melik Muzafferüddin'in 1247 ile 1272 yılları arasında vefat etmiş olabileceğini göstermektedir. $\mathrm{H}$. Önkal türbe ile ilgili tarihlendirme yaparken Melik Muzafferüddin'in babası Fahrettin Behram Şah ve dedesi Davut Şah'ın saltanat yılları ve ömürleri üzerinden bir hesaplama yaparak Melik Muzafferüddin'in 1260-1265 yılları arasında vefat etmiş olabileceğini türbenin de yakın bir tarihte inşa edilmiş olabileceğini ileri sürmektedir. ${ }^{20}$ Türbe, yanında inşa edilen medresenin inşa tarihi dikkate alınarak 1246'dan sonra yapılmış olmalıdır. 1272'deeki belgede Melik Muzafferüddin'in isminin yer almaması bu tarihten önce vefat ettiğini göstermektedir. Bu nedenlerle türbe 1247-1272 yılları arasında yapılmış olmalıdır. Ayrıca her iki yapıdaki süsleme üslubu benzerliği bu zaman aralığının daha da daralabileceğini göstermektedir.

Yap1, Mengücek Beyliğinin Şebinkarahisar kolunun emiri Muzafferüddin Muhammed adına inşa edilmiştir. I. Alâeddin Keykubat'ın 1228'de Mengüceklilerin Kemah kolunu ele geçirmesi ve emiri Davutşah'ı Konya Ilgın'a sürgün etmiş olması, Şebinkarahisar emri Muzafferüddin Muhammed'in anlaşma yoluna gitmesine neden olmuştur. I. Alâeddin Keykubat ve Muzafferüddin Muhammed arasında elçilik görevi üstlenen Atabey Mübarizeddin Ertokuş, emirin ikta isteğini sultana bildirmiş ve sultan Alâeddin Keykubat'da Kırşehir ve çevresindeki araziyi ikta olarak Muzaffereddin Muhammed ve üç oğluna vermiştir. ${ }^{21}$ Mengücek ailesi hakkında diğer bilgi ise Muzafferüddin Muhammed'in kızının II.Gıyasettin Keyhüsrev tarafından istenmesidir. Muzafferüddin Muhammed sultanı uygunsuz davranışlarının hanedanına yakışmayacağını düşündüğü için reddetmiştir. Daha sonra sultanın ısrarı üzerine evlilik isteğini kabul etmiştir. Böylece Anadolu Selçuklu hanedanı ile akraba olmuştur. ${ }^{22}$ Türbeyi yaptıran kadının Muzafferüddin Muhammed'in bir yakını olduğu açıktır. Ancak kitâbede bu bilgiye yer verilmemiştir.

\section{Türbe İle İlişkilendirilen Diğer Yapılar}

Melik Gazi Türbesinin yanında Melik Gazi Medresesi olarak bilinen bir medresenin bulunduğu ve yıkılan medresenin taçkapısının bugün Alâeddin Cami olarak bilinen yapıya taşındığ 1 kaynaklarda geçmektedir. 1858'de Kırşehir'i ziyaret eden Alman seyyahlar Heinrich Barth ve A.D. Mordtmann yapıdan kısa bir şekilde bahsetmektedir. ${ }^{23}$ Barth, kitabında şehirdeki iki medresenin varlığına işaret etmektedir. Bunlardan ilki Caca Bey Medresesi, diğeri ise Melik Gazi Medresesi'dir. Medresenin Caca Bey Medresesi'ne yakın bir konumda bulunduğu ve 1858 'de yapının medrese olarak kullanıldığından söz edilmektedir. Medresenin kîtâbesini de okuyan Barth, yapının II. İzzettin Keykavus döneminde Fahrettin Behramşah oğlu Melik Muffarettin tarafından yaptırıldığını belirtmektedir ayrıca yapım yılı olarak H. 644(1246) tarihini vermektedir. Seyyahın notlarından yapıda ikinci bir kîtâbe bulunduğu ve yapının H. 1269(1853)'da onarım geçirdiği bilgisi elde edilmektedir. Yazar, medresenin taçkapısının

\footnotetext{
${ }^{19}$ Cevat Hakkı Tarım, Tarihte Kırşehir Gülşehri ve Babailer-Ahiller-Bektaşiler, s. 49 d.n. 11

${ }^{20}$ Hakkı Önkal, Anadolu Selçuklu Türbeleri, s. 112.

${ }^{21}$ İbni Bibi, Anadolu Selçuklu Devleti Tarihi, (Çev. M.N. Gençosman) Uzluk Basımevi, Ankara,1942,s.140.

22 Age, s. 140.

${ }^{23}$ H. Barth, Relse Von Trapezunt Durch Die Nördlıche Hälfte Kleın-Asıens, Jüstus Perthes, Gotha,1860, s.72; H. Barth, Heinrich Barth Seyahatnamesi Trabzon'dan Üsküdar'a Yolculuk 1858,(Çev. T.Noyan), Kitap Yayınevi, İstanbul, 2017, s. 177; A.D. Mordtmann, Anatolien, Heinz Lafaire, Hannover, 1925, s. 511-512.
} 
oldukça bezemeli olduğunu ve diğer medreseye göre(Caca Bey Medresesi) süslemelerinin daha iri göründügünü söylemektedir. Barth'ın verdiği bilgiler medresenin 1858 'de sağlam ve kullanılır bir vaziyette olduğunu göstermektedir. (Fotoğraf:11)

Mordtmann'da aynı gün Kırşehir'i ziyaret etmiş ve neredeyse Barth'ın kurduğu cümlelerle notlar almıştır. Seyyah, Kırşehir'deki dört yapıdan bahsetmiştir. Melik Gazi Medresesi de ziyaret ettiği yapılardan biridir. Mordmann'ın yapı ile ilgili verdiği bilgiler Barth'ın ki ile aynıdır. Medresenin 1246'da II. İzzettin Keykavus'un saltanat yıllarında Melik Muzafferüddin tarafından yapıldığını gösteren inşa kîtâbesi ve 1853 yılında bir onarım geçirdiğini belirten bir tamir kîtâbesinden söz etmektedir. Ayrıca yine medresenin faal olarak kullanıldığı içinde Molla ve Sofilerin bulunduğunu belirtmektedir. Mordtmann'ın notlarında dikkat çekici diğer kısım kaledeki Alâeddin Cami olarak bilinen ve bugün Melik Gazi Medresesi’nin taçkapısının taşındığı yapıdan da bahsetmesidir. ${ }^{24}$ Seyyah bir tepede yıkıntı halinde bulunan bir cami olduğunu ve kîtâbesinden yapının II. Gıyasettin Keyhüsrev zamanında yapıldığg söylemektedir. Kîtâbede inşa tarihi ile ilgili bir ibarenin yer almadığından da söz edilmektedir. Yapı ile ilgili benzer bilgiler Barth'ın notlarında da yer almaktadır. ${ }^{25}$ Bu bilgiler Alâeddin Cami'nin yıkıntı halde olduğu 1858 y1lında Melik Gazi Medresesi’nin sağlam bir vaziyette olduğunu göstermesi bakımından ilginçtir. 1893 yılında Alâeddin Cami yeniden inşa edilirken ${ }^{26}$ Melik Gazi Medresesi bilinmeyen bir nedenle yıkılmış ve taçkapısı bu camide kullanılmıştır. Ayrıca bu durum medresenin cami için yıkılmış olabileceğini de düşündürmektedir.

Konu ile ilgili devlet arşivleri tarandığında Kırşehir kalesinde bulunan ve Alâeddin Keykubat'ın yaptırdığı caminin bilinmeyen bir nedenle yıkıldığı ve yerine 1893 'te bir cami yapıldığı anlaşılmaktadır. ${ }^{27}$ Başka bir kaynakta ise caminin 1895 yılında Kırşehir mutasarrıfı Arifi Bey tarafından tamir ettirildiği belirtilmektedir. ${ }^{28}$ Caminin girişi için de Melik Gazi Medresesi taçkapısı kullanılmıştır. Taçkapının üzerinde bir inşa kîtâbesi bulunmakla birlikte üzeri kazındığı için okunamamaktadır. Kazınmadan önce kîtâbeyi okuyan Ali Kemal Akyürek medresenin 1246 yılında II. İzzettin Keykavus'un saltanatı döneminde Muzafferüddin bin Melik Behramşah tarafından yaptırıldığını belirtmiştir. ${ }^{29}$ Bu okunuş Barth ve Mordtmann'ın bilgilerini de doğrulamaktadır.

Kırşehir'ın o dönemde bağlı olduğu Ankara Vilayet Salnameleri incelendiğinde 1883'ten 1907'ye kadar Kırşehir merkezde 4 medresenin bulunduğu anlaşılmaktadır. ${ }^{30}$ Bu sayıların yıllar içinde değişmemesi 1883-1907 yılları arasında Melik Gazi Medresesi'nin zaten yıkılmış olduğunu kanıtlamaktadır. Şayet Melik Gazi Medresesi bu medreselerin içinde sayılmış olsa idi bu sayının 3'e düşmesi beklenirdi çünkü medresenin 1890'larda yıkıldığı bilinmektedir.

\footnotetext{
${ }^{24}$ A.D. Mordtmann, age, s. 512.

${ }^{25}$ H. Barth, Heinrich Barth Seyahatnamesi Trabzon'dan Üsküdar'a Yolculuk 1858, s.178.

26 Metin Sözen, Anadolu Medreseleri Selçuklu ve Beylikler Devri, İstanbul Teknik Üniversitesi Matbaası, İstanbul,1972, s. 131.

27 BOA (Devlet Arşivleri Başkanlığı Osmanlı Arşivi), Kırşehir'de Sultan Alaeddin Şah zamanına ait olup tamirine müsaade edilen camiin padişahın adına tesmiyesinin Evkaf Nezareti'nce takdimi, 148-4 H-01-06-1314. https://www.devletarsivleri.gov.tr/(E.T. 15.10.2019)

${ }^{28}$ Mehmet Emin Kılıç, a.g.e., s. 246.

${ }^{29}$ Cevat Hakkı Tarım, Tarihte Kırşsehir Gülşehri ve Babailer-Ahiler-Bektaşiler, s. 40 d.n.2.

${ }^{30}$ Asuman Koçak, Salnamelere Göre Ankara Vilayeti (1871-1907), (Gazi Üniversitesi Sosyal Bilimler Enstitüsü Tarih Anabilim Dalı Yakınçağ Tarihi Bilim Dalı Basılmamış Yüksek Lisans Tezi), Ankara, 2013,s.101,124.
} 
Sayının düşmemesi medresenin 1858-1883 yılları arasında yıkılmış olabileceğini göstermektedir. Ancak neden yıkıldığ 1 ile ilgili bilgi bulunmamaktadır. Bu veriler Melik Gazi Medresesi'nin Alâeddin Cami'nin inşasından önce yıkılmış olduğunu kanıtlamaktadır. 18581883 arasındaki 25 yıllık süreçte medresenin neden ve nasıl yıkıldığına dair kaynaklarda bir bilgiye yer verilmemiştir. (Fotoğraf:1-2-3)

Kîtâbe metni ve tarihi veriler birleştirildiğinde Melik Gazi Medresesi ve türbesinin birbiri ile bağlantısı olduğu anlaşılmaktadır. Ayrıca türbenin de medrese ile aynı dönemde 1246 yılında yapılmış olduğu ya da yakın bir tarihte yapıya eklendiği varsayılabilir. Burada medresenin türbenin tam olarak hangi tarafında olduğu da önem taşımaktadır. Bazı kaynaklarda medresenin türbenin karşısında olduğ ${ }^{31}$ yazılırken, bazılarında yanında bulunduğu ${ }^{32}$ veya doğusunda yer aldığ $1^{33}$ yazmaktadır. Medresenin bulunduğu yer ile ilgili türbenin etrafında herhangi bir kalıntı bulunmamaktadır. Eski fotoğraflarda türbenin etrafında moloz yığını olduğu görülmekte ancak bunlar bir fikir vermemektedir. Konuyla ilgili türbenin konumu bazı fikirler vermektedir. Türbenin güneyden açılan kapısı, simetrik olarak üç yönde açılan pencerelerden birinin güneybatıya kaydırılması, mezar odası mazgal penceresinin sadece doğu cephede açılmış olması, türbenin her cephesindeki kenar süslemesinin batı cephesinde yapılmamış olması; medresenin türbenin batı cephesinde yer aldığına işaret etmektedir(Fotoğraf:9-10). Ayrıca türbenin planının medresenin konumuna göre şekillendirilmesi ve medrese bânîsi ve türbe bânîsinin farklı kişiler olması türbenin sonradan yapıya eklendiğini de kanıtlamaktadır. İki yapının muhtemelen birbirine bitişik olduğu fakat herhangi bağlantılarının olmadığ düşünülmektedir. Medresenin de taçkapısının güney cephede bulunduğu varsayılabilir.

Volume 12

Yapı ile ilişkilendirilen diğer yapı, aynı park içinde yer alan türbenin $50 \mathrm{~m}$. kuzeyindeki Lale Cami'dir. ${ }^{34}$ (Fotoğraf: 12-13) İnşa kîtâbesi bulunmayan yapının 13.yüzyılda inşa edildiği kabul edilmektedir. ${ }^{35}$ Bir diğer görüş ise caminin Melik Muzafferüddin tarafindan medrese ile birlikte 1246 'da inşa edildiğidir. ${ }^{36}$ Bugün cami olarak kullanılan yapının ilk halinde hangi amaçla inşa edildiği de bilinmemektedir. Yapının İlhanlı ve Eratna döneminde darphane olarak kullanıldığ 1 söylenmektedir. ${ }^{37}$ Kimi kaynaklar ise Caca Bey Vakfiyesinde bahsedilen Melik Muzafferrüddin Han'ının bu yapı olduğunu belirtmektedir. ${ }^{38}$ Mustafa Kemal Şahin yapının cami olarak tasarlandığı ve özgün planının mihraba dik üç sahınlı ve orta sahnın kubbelerle örtülmüş olabileceği belirtmektedir. ${ }^{39}$ Diğer bir fikir, yapının han olarak inşa edildiği, İlhanlı döneminde darphane olarak kullanıldığı, Osmanlı döneminde de camiye dönüştürüldüğüdür. ${ }^{40}$ Cami ile

${ }^{31}$ Cevat Hakkı Tarım, Kırşehir Tarihi, s.52-53.

${ }^{32}$ Metin Sözen, age, s. 130-131.

${ }^{33}$ Mehmet Emin Kılıç, a.g.e., s.242.

${ }^{34}$ W. Ruben, Kırşehir'in Dikkatimizi Çeken Sanat Eserleri ,(Çev. A. İtil), Belleten, C. XI, S. 44, Ankara,1947, s. 613.

${ }^{35}$ Keriman Tüzün, Türk Devri Kırşehir Yapıları, (Marmara Üniversitesi Atatürk Eğitim Fakültesi Basılmamış Doktora Tezi), İstanbul,1983, s. 10.

${ }^{36}$ Mustafa Kemal Şahin, Anadolu'da Selçuklu Dönemi Camileri-I Boyuna (Derinlemesine/Dikine Düzenlemeli Camiler, Ankara, 2014, s. 76.

${ }^{37}$ Cevat Hakkı Tarım, Tarihte Kırşehir Gülşehri ve Babailer-Ahiler-Bektaşiler, s. 41.

${ }^{38}$ Mehmet Emin Kılıç, 13.-14.Yüzyıllarda Kırş̧ehir ve Yöresinin Siyasi Sosyal Kültürel ve Dini Tarihi, (Gazi Üniversitesi Sosyal Bilimler Enstitüsü Ortaçağ Bilim Dalı Basılmamış Yüksek Lisans Tezi), Ankara,2006,s. 51.

${ }^{39}$ Mustafa Kemal Şahin, a.g.e., s.78.

${ }^{40}$ Cevat Hakkı Tarım, Tarihte Kırşehir Gülşehri ve Babailer-Ahiler-Bektaşiler, s. 41.

\section{History Studies}


ilgili son yayın O. Eravşar tarafından hazırlanmıştır. Eravşar, yapıda yürütülen sondaj çalışmaları, plan, süsleme, malzeme ve teknik özelliklerini dikkate alarak eserin, dikine üç sahınlı, bazilikal planlı olduğunu ve sonradan camiye dönüştürüldüğü belirtmektedir. ${ }^{41}$ Planından yola çıkarak yapının özgünün bir ticaret yapısı olduğu ve Moğol öncesi dönemde yapılmış olabileceği üzerinde durulmaktadır. ${ }^{42}$ Selçuklu dönemi süsleme üslubu özellikleri taşıyan mihrabın da başka bir yapıdan taşınmış olabileceğinden bahsedilmektedir. ${ }^{43}$ Türbe, medrese ve caminin konumları üç yapının bağlantısı ile ilgili bir bilgi vermemektedir. Ancak cami, medrese ve türbenin oldukça yakın olması, üç yapının da 13. yüzyılda inşa edilmiş olması, caminin medrese ve türbe ile bir ilişkisi olabileceğini akla getirmektedir. Lale Cami olarak bilinen yapının ilk inşasında medrese ile birlikte yapıldığı, daha sonra bu yapı topluluğuna türbenin dâhil edildiği ve Lale Cami'nin de bânîsinin Melik Muzafferüddin olabileceği düşünülmelidir. Bugün Lale Cami olarak bilinen yapının da bir kompleksin parçası olarak yapıldığı varsayılmaktadır. Yapının ilk işlevinin ise hankâh olabileceği düşünülmektedir. Dönemin siyasi ve kültürel ortamında sayıları artan hankahların planlarının belli bir tipinin olmaması, aynı dönemde Aksaray'da inşa edilen Melik Mahmut Gazi Hankahı için de benzer şekilde darphane ibaresinin kullanılması ${ }^{44}$ ve Aksaray Şeyh Cemalettin Zaviyesi'nin ${ }^{45}$ de Lale Cami'nin planına yakın bir tasarımda olması yapının özgününde hankah olarak yapılmış olabileceğini düşündürmektedir. Melik Muzafferrettin'in medrese ile birlikte bir hankah inşa etmiş olabileceği de hesaba katılmalıdır. Yapının bugünkü planı, güney cephede açıklanamayan duvar kalıntıları, batı ve doğu cephesinde değişimler 13. yüzyıl zaviye hankah plan örneklerinde görüldüğü gibi düzensiz bir şemaya işaret etmektedir.

Birbiri ile ilişkili olduğu düşünülen bu yapıların dikkat çekici ortak özelliklerinden biri de süsleme üsluplarıdır (Fotoğraf:14-15-16). Medrese ve türbenin taçkapıları ve Lale Cami harim kısmı girişindeki lento taşı olarak kullanılan süslemeli parça ve mihrabı teknik ve üslup bakımından incelediğinde yapıların dönem ayrımı ile ilgili fikirler ortaya çıkmaktadır. $\mathrm{Bu}$ durum medrese ve türbenin süsleme üsluplarının benzer özellikler taşımasının yanında farklı dönemlerde inşa edilmiş olduklarını bir kez daha göstermektedir. Türbe taçkapısında yoğunlaşan bezeme karakteristik olarak medrese taçkapısı ile oldukça benzerdir. Ancak kullanılan teknik ve üslup türbedeki süslemenin daha geç yapılmış olabileceğini düşündürmektedir (Fotoğraf:18-19). Lale Cami'ndeki mimari parça ise yeniden kullanım olmalıdır. Bu parça medrese taçkapısının en dış süsleme şeridi ile birebir uyuşmaktadır. Birkaç onarım geçiren Lale Cami'inde yıkılan medresenin parçaları da kullanılmış olabileceği akla gelmektedir. ${ }^{46}$ Ayrıca Lale Caminin medrese ile beraber inşa edildiği ve mihrap ile süsleme

\footnotetext{
${ }^{41}$ Osman Eravşar, 'Kırşehir Lala Camisinin İnşa Süreci Üzerine Gözlemler', III. Uluslararası Akdeniz Sanat Sempozyumu Kültürel Mirasın Korunması ve Yaşatılması Antalya, 2018, s. 511.

42 Agm, s. 511.

${ }^{43}$ Agm, s. 511.

${ }^{44}$ Zekai Erdal, Aksaray Türk Devri Mimarisi, (Yüzüncü Y11 Üniversitesi Sosyal Bilimler Enstitüsü Sanat Tarihi Ana Bilim Dalı Basılmamış Doktora Tezi), Van, 2014, s. 226.

${ }^{45}$ Seval Bal, Aksaray Il Merkezindeki Tarikat Yapıları, (Gazi Üniversitesi Sosyal Bilimler Enstitüsü Sanat Tarihi Ana Bilim Dalı Sanat Tarihi Bilim Dalı Basılmamış Yüksek Lisans Tezi), Ankara, 2010,s.112.

${ }^{46}$ Yunus Aslan, Kırşehir Merkez Türk Devri Yapılarında Taş Süsleme (13-14. Yüzyıl), (Selçuk Üniversitesi Sosyal Bilimler Enstitüsü Sanat Tarihi Anabilim Dalı Sanat Tarihi Bilim Dalı Basılmamış Yüksek Lisans Tezi), Konya, 2018, s. 10.
} 
parçasının yapının başka bir yerinden camiye dönüştürüldüğünde bu kısımlara eklendiği düşünülebilir. Medresenin 1858'e kadar ayakta ve faal olduğu bilinmektedir. Medresenin taçkapısının taşıdığı Alâeddin Cami'nin 1894'te inşa edildiği ve Ankara Salnamesinde medresenin 1883 'te var olmadığ arasında bilinmeyen bir sebeple yıkıldığı ortaya çıkmaktadır. Medrese ile birlikte inşa edilen Lale Cami yapının yıkılması ile işlev değişikliğine uğramış olabilir. Ancak bu durumu kanıtlayacak herhangi bir belge bulunmamaktadır. Eravşar'ın başka bir yapıdan getirilmiş olabileceğini belirttiği mihrabın da medreseden getirildiği düşünülebilir. Mihraptaki süsleme üslubunun daha sade olmakla birlikte taçkapı ve türbedeki geometrik bezeme teknikleri ile benzerlikler barındırması da bunu desteklemektedir.

Yapıların süsleme özellikleri dönem yapıları ile karşılaştırıldığında özellikle Kayseri, Sivas ve Tokat'taki 13. yüzyılın ikinci yarısı sonrasında inşa edilen yapılardaki süslemelerle bir üslup benzerliği görülmektedir. Kayseri Çifte Kümbet(1247) taçkapısı, Hacı Kılıç Cami(1249-1250) doğu taçkapısı, Sahip Ata Medresesi(1266-1268) taçkapısı, Develi Hızır İlyas Türbesi (1252) taçkapısı ve mihrabı, Sivas Çifte Minareli Medrese (1271) taçkapısı ve pencere çerçeveleri, Gök Medrese(1271) taçkapısı, Tokat Sünbül Baba Zaviyesi (1291-1292) taçkapısında Melik Gazi Medresesi, türbesi ve Lale Cami'inde görülen bitkisel ve geometrik süslemelerle benzer üslupta bezenmişlerdir. Bu benzerlikler süsleme üslubuna bakılarak türbenin 1246-1290 yılları arasında yapılmış olabileceğini göstermektedir.

Sivas Gök Medrese, Tokat Sünbül Baba Zaviyesi ile Kırşehir Melik Gazi Medresesi ve Türbesi arasında benzer bir diğer durum taçkapılarında kullanılan mermerdir. 13. yüzyılın ikinci yarsında inşa edilen yapılarda mermer kullanımın arttığı anlaşılmaktadır. Mermer ayrıca bânîlerin prestij için yaptırdıkları eserlerde tercih ettikleri bir malzemedir. Melik Muzafferüddin'in Kırşehir'de önemli bir konumda olduğu malzeme tercihi ile de ortaya çıkmaktadır.

\section{Sonuç}

Kırşehir Melik Gazi türbesi kîtâbesi ve çevresindeki yapılarla ilgili bilgi ve değerlendirmeler bir araya getirildiğinde, yapı ile ilgili sorulara alternatif cevaplar ortaya çıkmaktadır. Yapının türbe olduğu ve Melik Muzafferüddin'in bânîsi olduğu medresenin türbenin batı cephesinde yanında bulunduğu net bir şekilde anlaşılmaktadır. Türbe, muhtemelen Melik Muzafferüddin için yaptırılmıştır. Kîtâbesinde bu durum net olmasa da yapının halk arasında anılan adı ve Melik Muzafferüddin'in medresesinin yanında yapılmış olması bu olasılığ 1 güçlendirmektedir. Lale Cami olarak bilinen yapının ilk hali medrese ile alakalı imaret, hankâh gibi bir yapı türü olmalıdır. Türbenin 1247-1272 yıllarında yapılmış olabileceği düşünülmektedir. Medrese ve Lale Cami'nin aynı dönemde yapılmış olduğu kabul edilirse türbenin bu tarihten sonra Melik Muzafferüddin'in vefatı üzerine yapıldığı anlaşılmaktadır. Türbe ve medrese taçkapısı süslemelerindeki üslup birliği bu zaman aralığının çok uzak olamayacağını göstermektedir. İki yap1 süsleme kompozisyonları arasındaki benzerlik; türbenin özellikle medrese süslemesi dikkate alınarak bezendiğini düşündürmektedir. $\mathrm{Bu}$ nedenlerle iki yapı arasında zaman aralığının 10 yıldan daha kısa bir süre olması beklenmektedir. Bu yüzden türbenin 1247-1257 yılları arasında inşa edilmiş olduğu varsayılabilir. Türbenin süsleme üslubu olarak benzediği

\section{History Studies}


Kayseri'deki Hacı Kılıç Cami ve Medresesi(1249-1250) ve Sahip Ata Medresesi(1266-1268) de bu tarihlendirmenin doğru olabileceğini göstermektedir.(Fotoğraf: 23-24-25-26)

Medresenin zamanında okunmuş inşa kîtâbesi ve türbe inşa kîtâbesi birlikte ele alındığında birbirini tamamlayan ifadelerin varlı̆̆ dikkat çekmektedir. Medrese kîtâbesinde yer alan saltanat dönemi ve yıl ifadeleri türbe kîtâbesinde kullanılmamıştır. Türbe kîtâbesinde kullanılan Hanefi ve Şafi mezhep vurgusu ise medrese ile direkt ilişkili olmasına rağmen türbe kîtâbesinde yer almaktadır. Bu nedenle türbe kîtâbesinin medreseye ait olabileceği ve sonradan medreseye dâhil edilen türbeye yerleştirilmiş olabileceği de düşünülmelidir. Bu olasılık türbe kîtâbesindeki mezhep vurgulu farklı kullanımını da açıklamaktadır. Ancak medrese ve türbe kîtâbelerinde iki farklı isimle karşılaşılmaktadır. Medrese kîtâbesinde Melik Muzafferüddin bânî olarak yer alırken; türbe kîtâbesinde Melik Muzaferüddin'in hareminden isminin Emete olduğu anlaşılan bir kadın bulunmaktadır. Türbedeki isim farklılığı yapının sonradan Melik Muzaferettin Medresesine eklendiği ve Melik Muzaferettin'in hayatta olmadığına bu nedenle türbenin onun adına inşa edilmiş olduğuna işaret etmektedir. Emete Hatun'un bânîlik yapmasından yola çıkılarak Mengücekli ailesi için önemli biri olduğu düşünülmelidir. Melik Muzafferüddin'in yaptırdığı bir esere eklemelerde bulunmak için ona oldukça yakın olmak ve maddi bir gelirinin olması gerekmektedir. Bu durumda benzer yapılar da dikkate alınarak Emete Hatun'un Melik Muzafferüddin eşi olduğu varsayılabilir.

Kîtâbe ile ilgili diğer konu haze sözcüğünden sonra gelen kelimenin okunuşudur. Yakından incelenen kîtâbenin bu kısmının H. Önkal'ın da bahsettiği gibi kîtâbenin genelinde yapılan imla ve yazım hatalarından biri olduğu fikri ağır basmaktadır. Buka kelimesindeki (ق ) harfinin kıvrımı yapılmadığından ( $)$ harfi gibi okunmaktadır. Ancak cümlenin ve kîtâbenin anlam bütünlügünün sağlanması için kelimenin (بقعة) şeklinde yazılmış olması gerekmektedir.

Yap1 topluluğu ile ilgili genel değerlendirmeler bir araya getirildiğinde; 1246'da inşa edilen medrese ve muhtemelen etrafında inşa edilen diğer yapı, sonrasında yaptırılan türbe bir kompleksin parçasıdır. Medrese ve diğer yapının bânîsi Melik Muzaferettin, türbenin bânîsi Melik Muzaferettin'in bir yakını olan Emete Hatun'dur.

Kırşehir Melik Gazi Türbesi hem mimari hem de tarihi olarak Kırşehir'in Ortaçağ dönemi için önemli bir yapıdır. Melik Muzafferüddin'e ikta olarak verilmesi ile birlikte şehrin çehresinin değiştiği anlaşılmaktadır. Mengücekli ailesinin şehre yerleştiği ilk dönemden itibaren bânîlik faaliyetlerine başladığı günümüze gelemeyen ancak literatüre geçmiş yapılarından anlaşılmaktadır. Kırşehir'de Melik Muzafferüddin ile birlikte ve daha sonra Moğol işgali ile şehre göç eden halkın ihtiyaçlarını karşılamak üzere çeşitli yapılar inşa edildiği, imar faaliyetlerinin bu göçlerle paralel bir seyir izlediği düşünülmektedir. Melik Muzafferüddin ve ailesi Anadolu Selçuklu hanedanıyla akraba olmanın da vermiş olduğu ayrıcalıkla Kırşehir'in öncü ve büyük bir ailesi olmuştur. Bu ailenin günümüze gelebilmiş tek eseri de Melik Gazi Türbesi'dir. 


\section{Kaynakça}

ASLAN Yunus, Kırşehir Merkez Türk Devri Yapılarında Taş Süsleme (13-14. Yüzyıl), (Selçuk Üniversitesi Sosyal Bilimler Enstitüsü Sanat Tarihi Anabilim Dalı Sanat Tarihi Bilim Dalı Basılmamış Yüksek Lisans Tezi), Konya, 2018.

BAL Seval, Aksaray Il Merkezindeki Tarikat Yapıları, (Gazi Üniversitesi Sosyal Bilimler Enstitüsü Sanat Tarihi Ana Bilim Dalı Sanat Tarihi Bilim Dalı Basılmamış Yüksek Lisans Tezi), Ankara, 2010.

BARTH H. Relse Von Trapezunt Durch Die Nördlıche Hälfte Kleın-Asıens, Jüstus Perthes Gotha, 1868 .

BARTH H. Heinrich Barth Seyahatnamesi Trabzon'dan Üsküdar'a Yolculuk 1858,(Çev. T.Noyan), Kitap Yayınevi, İstanbul,2017.

İBNİ BİBİ, Anadolu Selçuki Devleti Tarihi. (Çev. M. N. Gençosman), Uzluk Basımevi, Ankara,1941.

ERAVŞAR Osman Kırşehir Lala Camisinin İnşa Süreci Üzerine Gözlemler. III. Uluslararası Akdeniz Sanat Sempozyumu Kültürel Mirasın Korunması ve Yaşatılması, Akdeniz Üniversitesi, Antalya,2018, s. 506-523.

ERDAL Zekai, Aksaray Türk Devri Mimarisi, (Yüzüncü Yıl Üniversitesi Sosyal Bilimler Enstitüsü Sanat Tarihi Ana Bilim Dalı Basılmamış Doktora Tezi), Van, 2014.

KILIÇ Mehmet Emin, 13.-14.Yüzyıllarda Kırşehir ve Yöresinin Siyasi Sosyal Kültürel ve Dini Tarihi, (Gazi Üniversitesi Sosyal Bilimler Enstitüsü Ortaçağ Bilim Dalı Basılmamış Yüksek Lisnas Tezi), Ankara,2006.

KILIÇ Mehmet Emin, Selçuklu Döneminde Kırşehir, XIII-XIV. Yüzyıllarda Kırşehir ve Yöresinin Siyasi, Sosyal, Kültürel ve Dini Tarihi, Kırşehir Valiliği Yayınları, Yayın No:33, Basım Yeri ve Y1l Bulunmuyor.

KOÇAK Asuman, Salnamelere Göre Ankara Vilayeti (1871-1907), (Gazi Üniversitesi Sosyal Bilimler Enstitüsü Tarih Anabilim Dalı Yakınçağ Tarihi Bilim Dalı Basılmamış Yüksek Lisans Tezi), Ankara,2013.

KUNTER Halim Baki, 'Kitâbelerimiz I', Vakıflar Dergisi, S. 2,Ankara,1942, s. 431-455.

MORDTMANN A. D., Anatolien, Orientbuchhandlung Heinz Lafaire, Hannover, 1925.

MUTÇALI Serdar, Arapça-Türkçe Sözlük, Dağarcık, İstanbul,1995.

ÖNKAL Hakkı, Anadolu Selçuklu Türbeleri, Atatürk Kültür Merkezi Yayınları, Ankara, 2015.

ÖNKAL Hakkı, 'Epigrafik Metinlerin Deşifresinde Takip Edilebilecek Usul Hakkında Düşünceler', Prof. Dr. Selçuk Mülayim Armağanı: Sanat Tarihi Araştırmaları (Edt. Aziz Doğanay), Lale Yayınevi, İstanbul,2017, s. 29-38.

ÖZKURT Kemal - TÜFEKÇİOĞLU Abdülhamit, "Türk-İslam Sanatında Kitabeler”, Türkiye Araştırmaları Literatür Dergisi, C. 7, S. 14, 2009, s.275-295. 
RUBEN W., 'Kırşehir'in Dikkatimizi Çeken Sanat Eserleri', (Çev.A. İtil), Belleten, C. XI S. 44, Ankara, 1947, s. 604-640.

SÖZEN Metin, Anadolu Medreseleri Selçuklu ve Beylikler Devri, İstanbul Teknik Üniversitesi Matbaası, İstanbul, 1972.

ŞAHIN Mustafa Kemal, Anadolu'da Selçuklu Dönemi Camileri-I Boyuna(Derinlemesine/Dikine) Düzenlemeli Camiler, Merdiven Yayın, Ankara, 2014.

TARIM Cevat Hakkı, Kırşehir Tarihi, Kırşehir Vilayet Matbaası, Kırşehir,1938.

TARIM Cevat Hakkı, Tarihte Kırşehir Gülşehri ve Babailer-Ahiller-Bektaşiler, Yeniçağ Matbaası İstanbul,1948.

Derleme Sözlüğ̈̈(Türkiye Türkçesi Ağızları Sözlüğ̈̈), Türk Dil Kurumu, C. 5, Ankara Üniversitesi Basımevi, Ankara,1995.

TOY Lokman, Kırşehir(Merkez) Türbeleri, (Gazi Üniversitesi Sanat Tarihi Anabilim Dalı Basılmamış Yüksek Lisans Tezi), Ankara, 2010.

TUNCER Orhan Cezmi, Anadolu Kümbetleri I Selçuklu Dönemi, Güven Matbaası, Ankara,1986.

TÜFEKÇİOĞLU Abdülhamit, Kişisel Görüşme, 01.12. 2016.

TÜRKMEN Kerim, 'Kayseri'de İmar Faaliyetine Katkıda Bulunan Hanımlar', II. Uluslararası Ahilik Sempozyumu Ahilikte Kadının Yeri, Kayseri,2012, s. 20-54.

TÜZÜN Keriman, Türk Devri Kırşehir Yapıları, (Marmara Üniversitesi Atatürk Eğitim Fakültesi Basılmamış Doktora Tezi), İstanbul,1983.

ÜLGEN Ali Sami, ‘Kırşehir'de Türk Eserleri’, Vakıflar Dergisi, S 2, Ankara,1942, s. 253-263.

\section{İnternet Kaynakları}

https://www.devletarsivleri.gov.tr/(E.T. 15.10.2019)

http://ktp.isam.org.tr/salname(E.T.15.10.2019) 


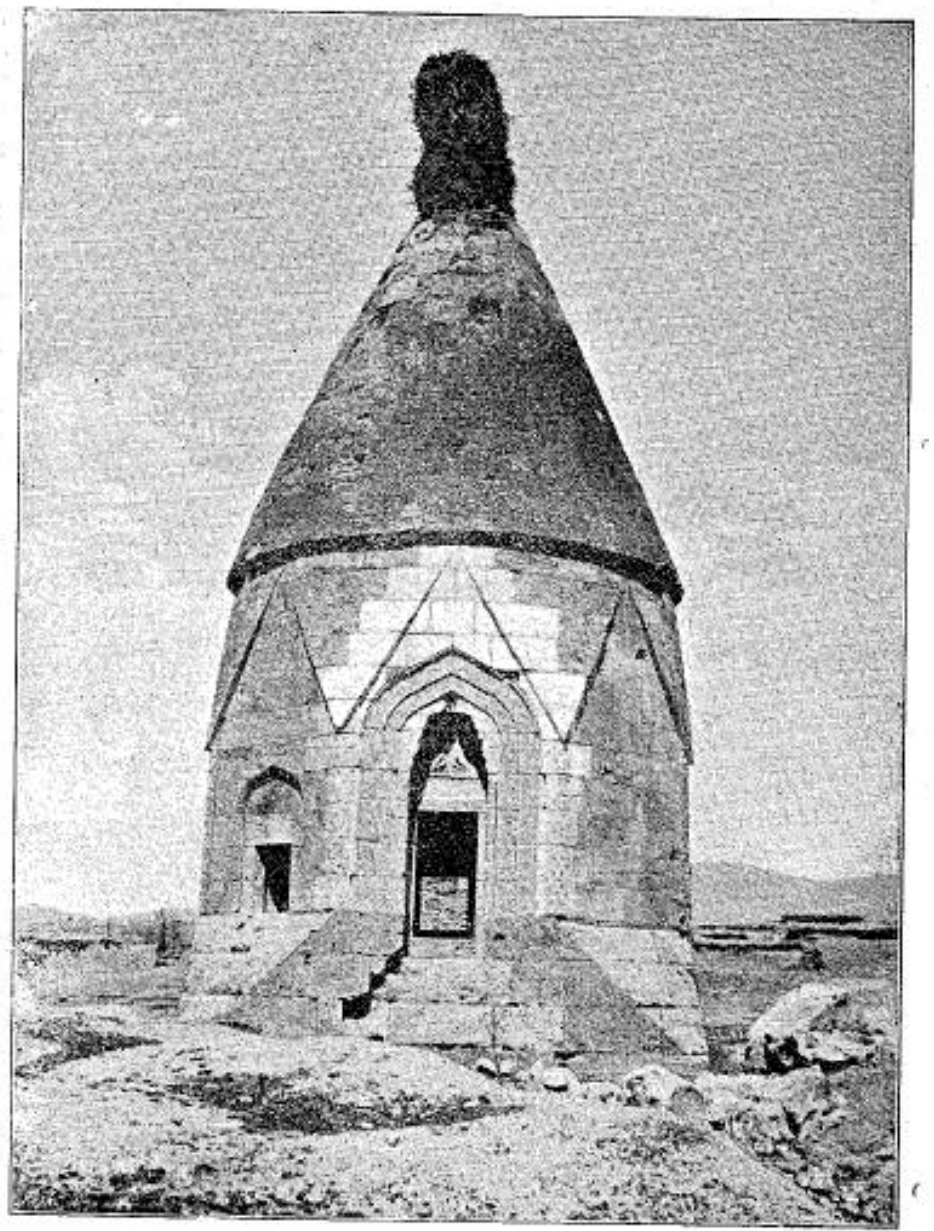

Fotoğraf 1: Melik Gazi Türbesi(H.1325(1907) Ankara Vilayet Salnamesi) http://ktp.isam.org.tr/salname(E.T.15.10.2019) 

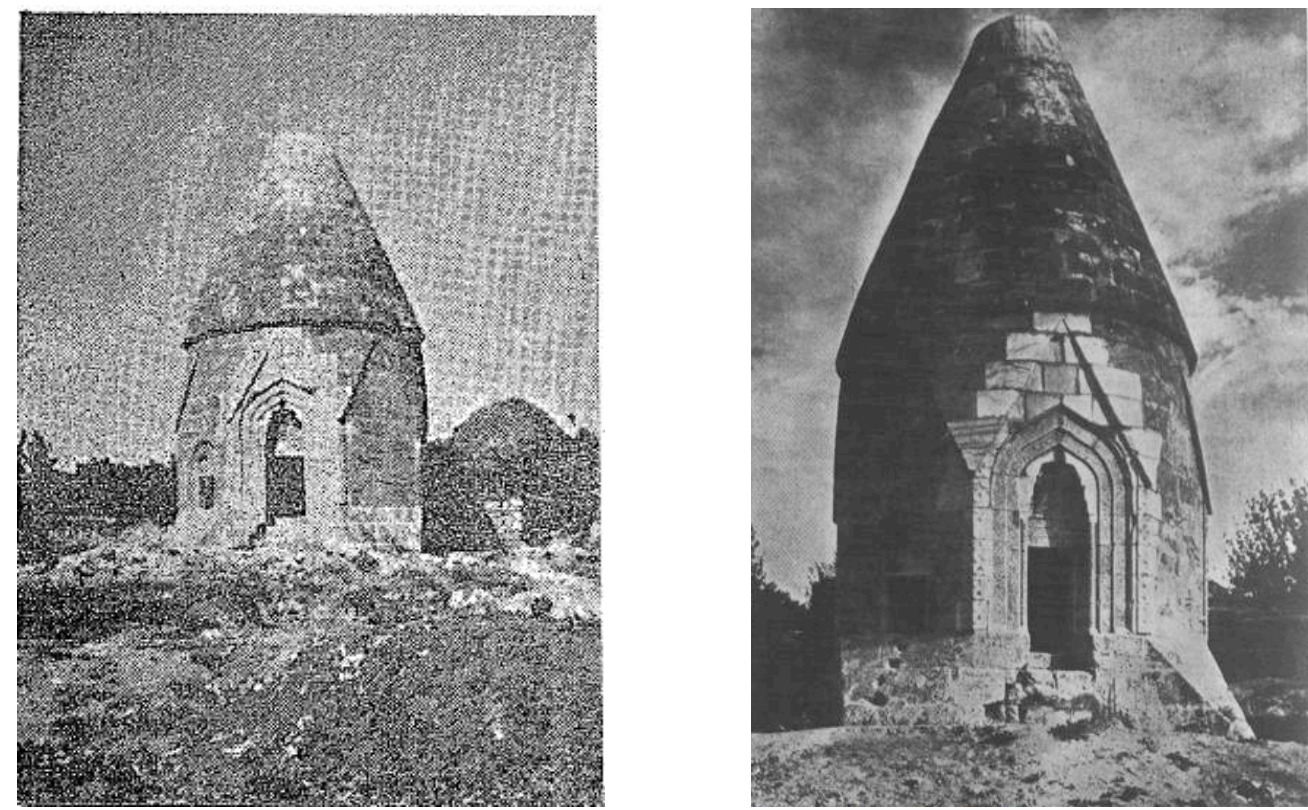

Fotoğraf 2-3: Melik Gazi Türbesi (Tarım, 1948-Ülgen,1942)
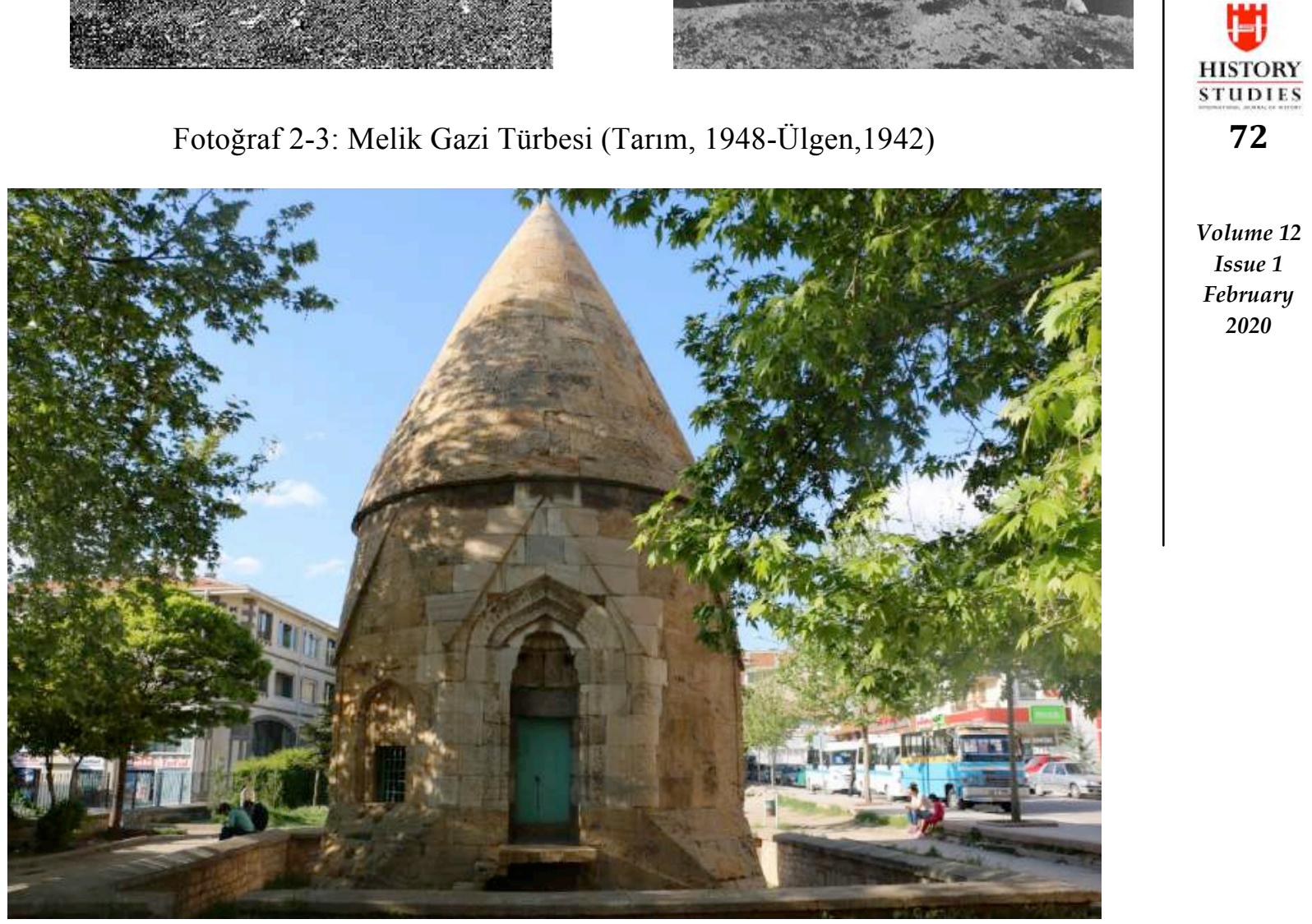

Issue 1

2020

Fotoğraf 4: Melik Gazi Türbesi 


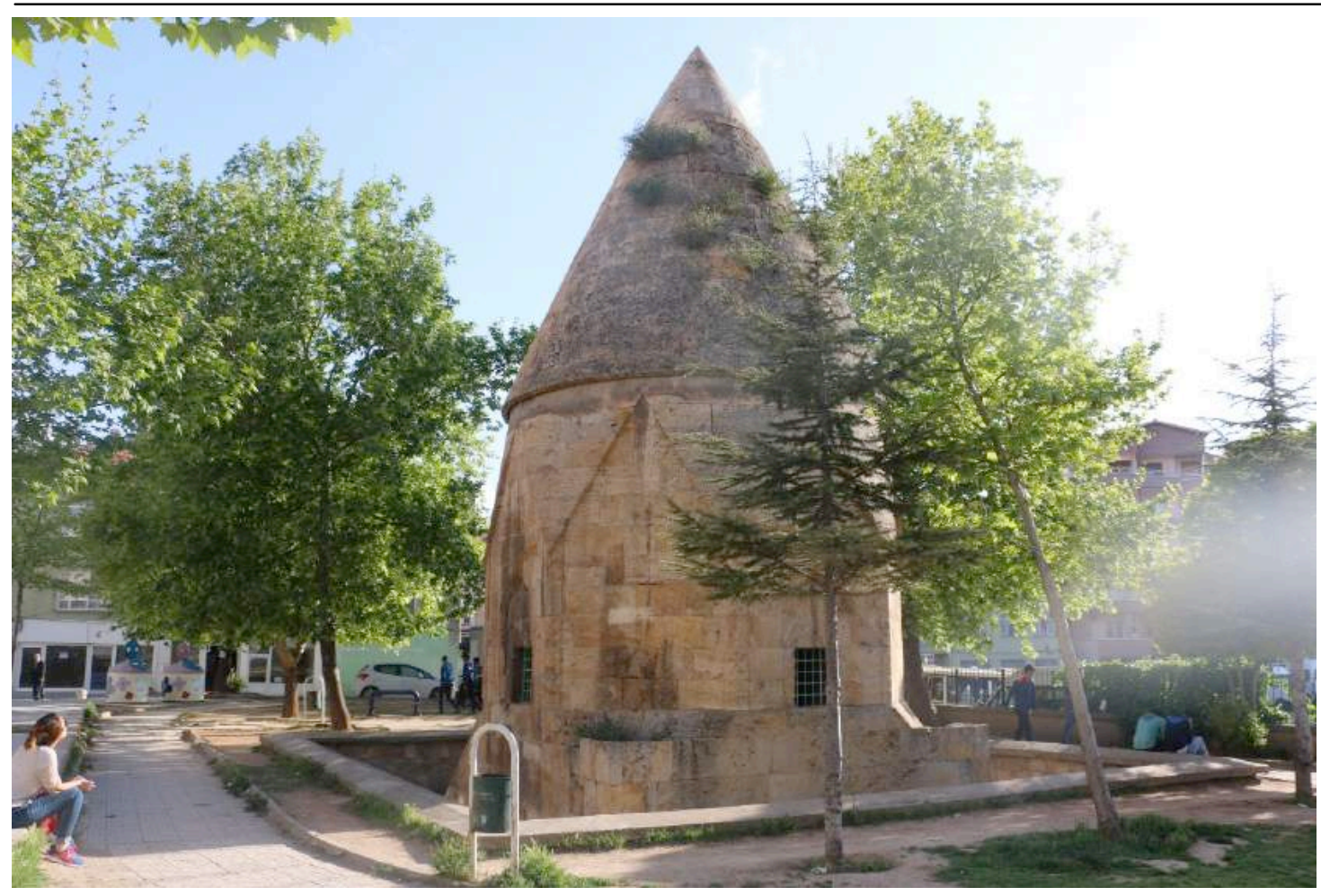

Fotoğraf 5: Melik Gazi Türbesi

Volume 12

Issue 1

February

2020

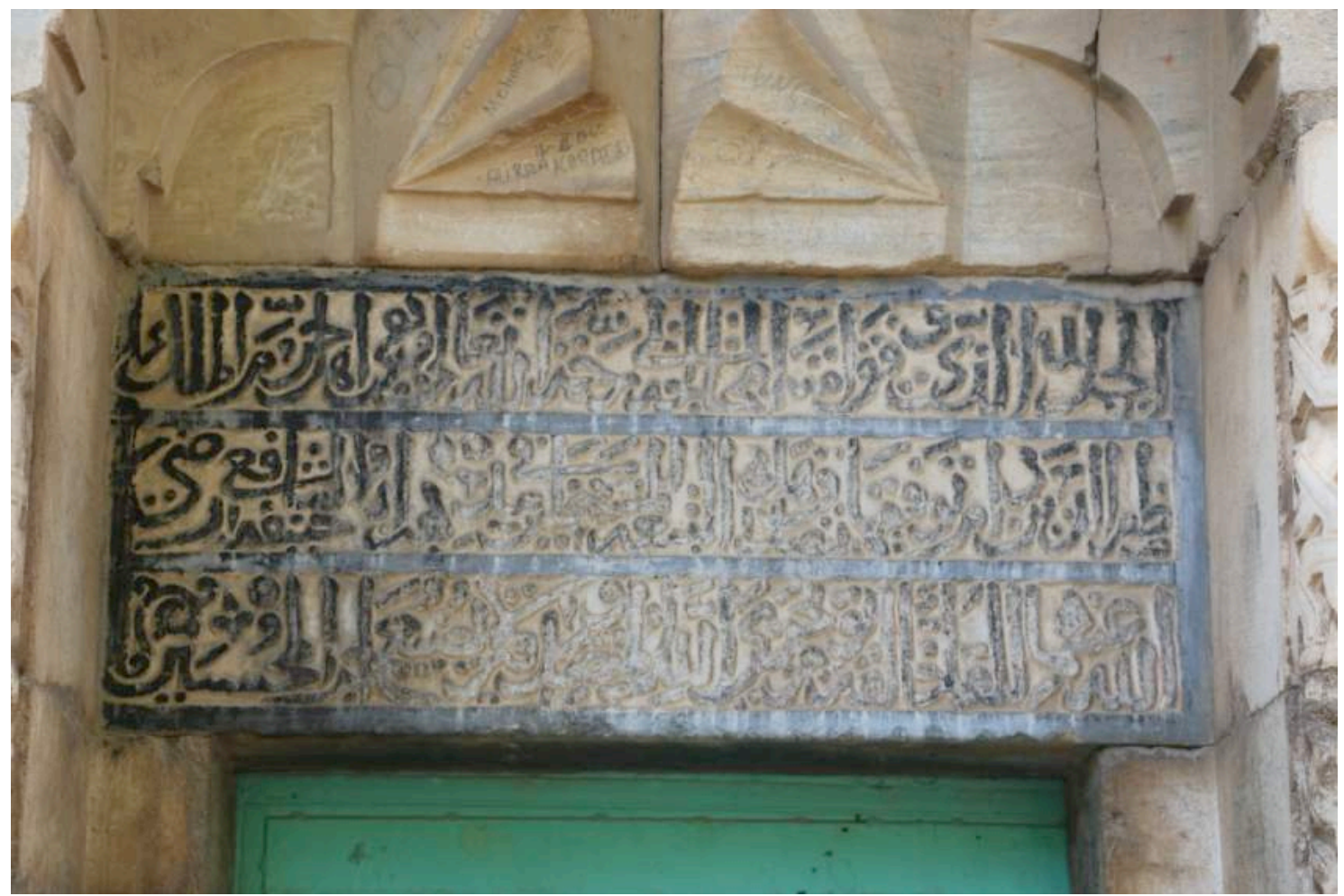

Fotoğraf 6: Melik Gazi Türbe Kîtâbesi

\section{History Studies}



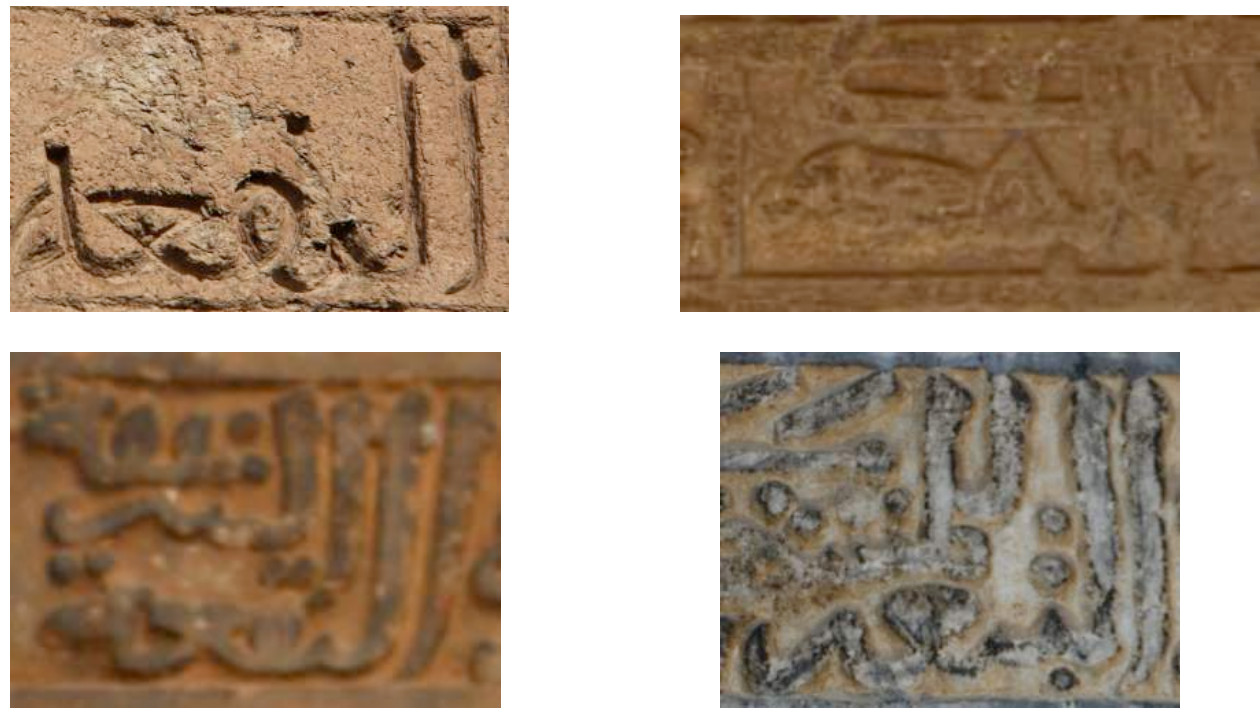

Fotoğraf 7: Ahlat Şeyh Necmettin Türbesi- Harput Arap Baba Türbesi- Tokat Halef Sultan Zaviyesi- Kırşehir Melik Gazi Türbesi Kîtâbelerinde ‘Buka’ geçen kısımlar 


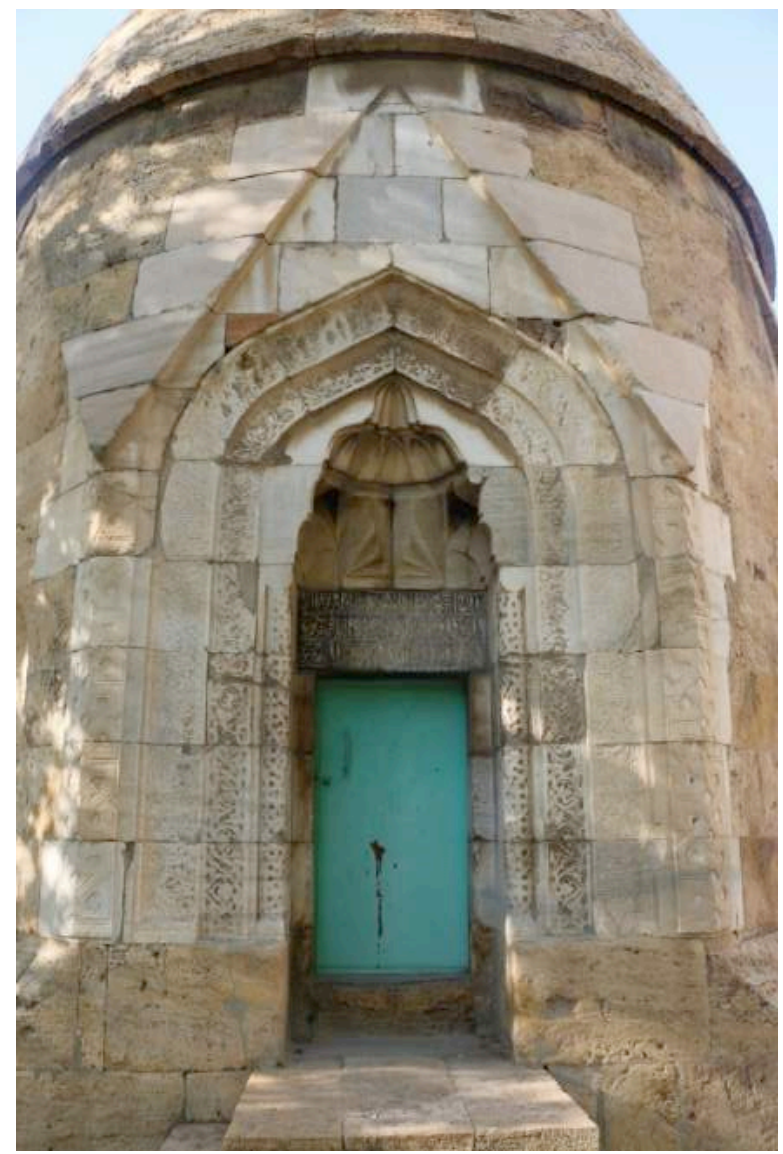

Fotoğraf 8: Melik Gazi Türbesi Taçkapısı 
Kırşehir Melik Gazi Türbesi Üzerinden Yeni Bir Değerlendirme

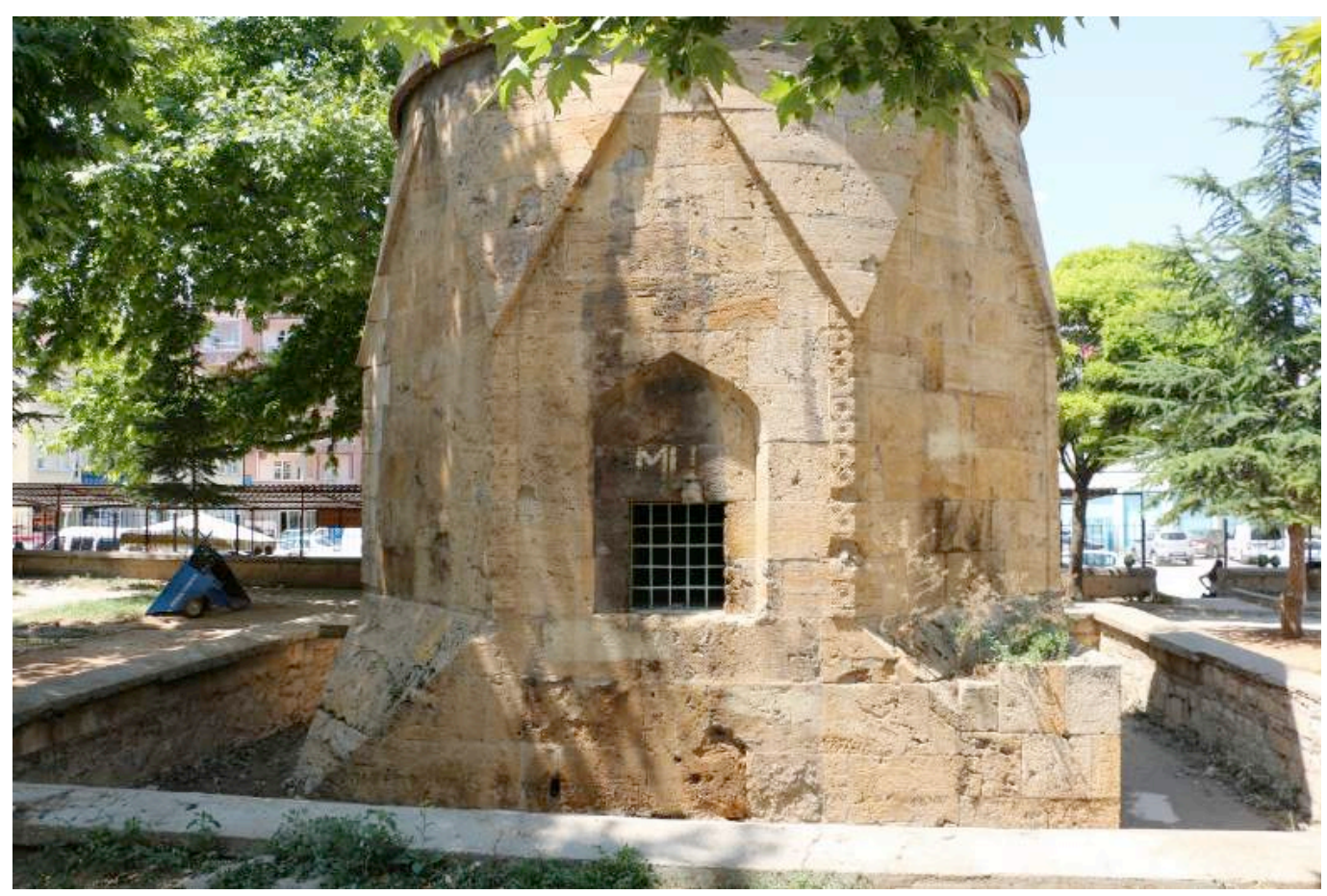

Fotoğraf 9: Melik Gazi Türbesi doğu cephesi

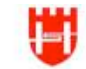

HISTORY STUDIES

76

Volume 12

Issue 1

February

2020

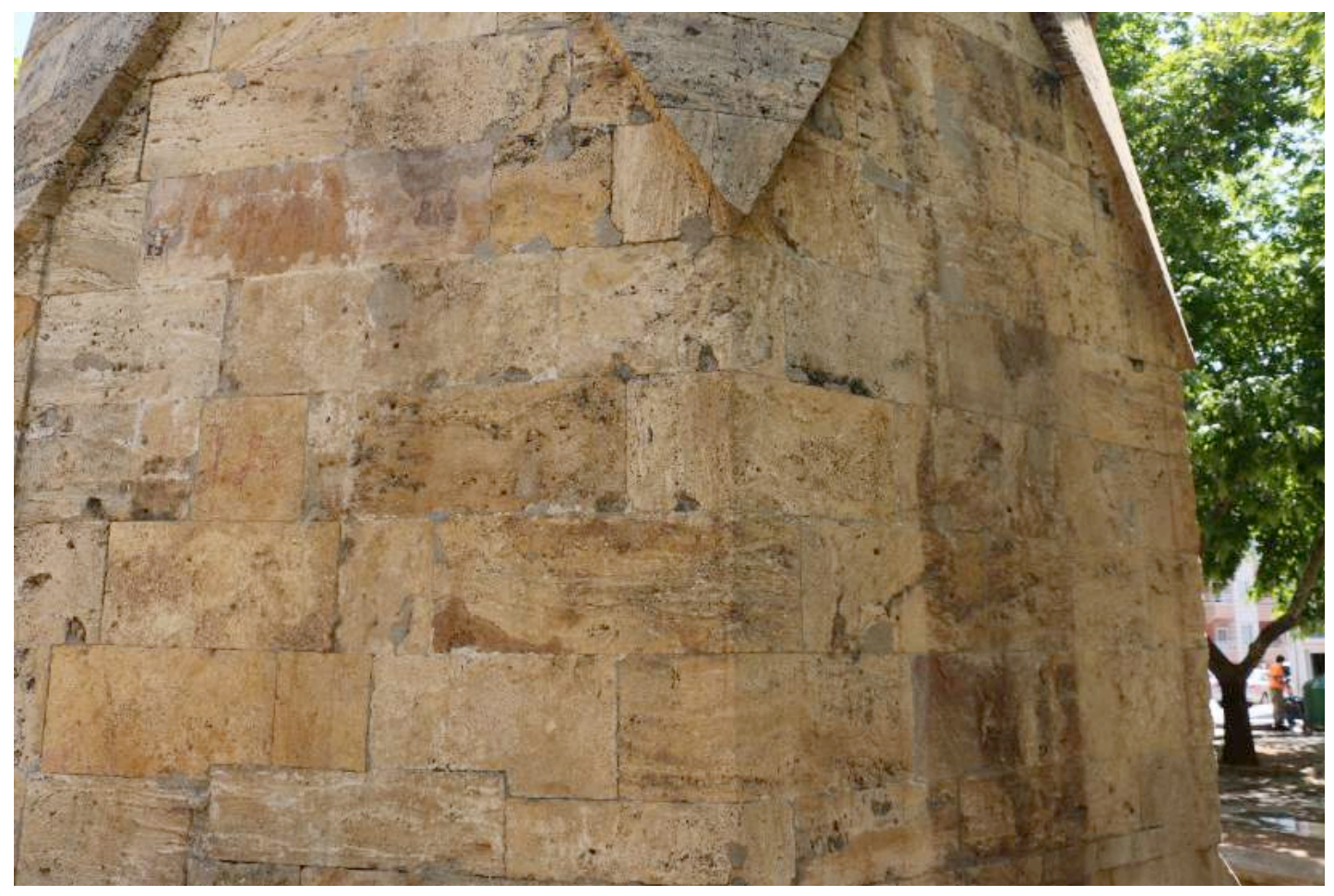

Fotoğraf 10: Melik Gazi Türbesi batı cephesi 


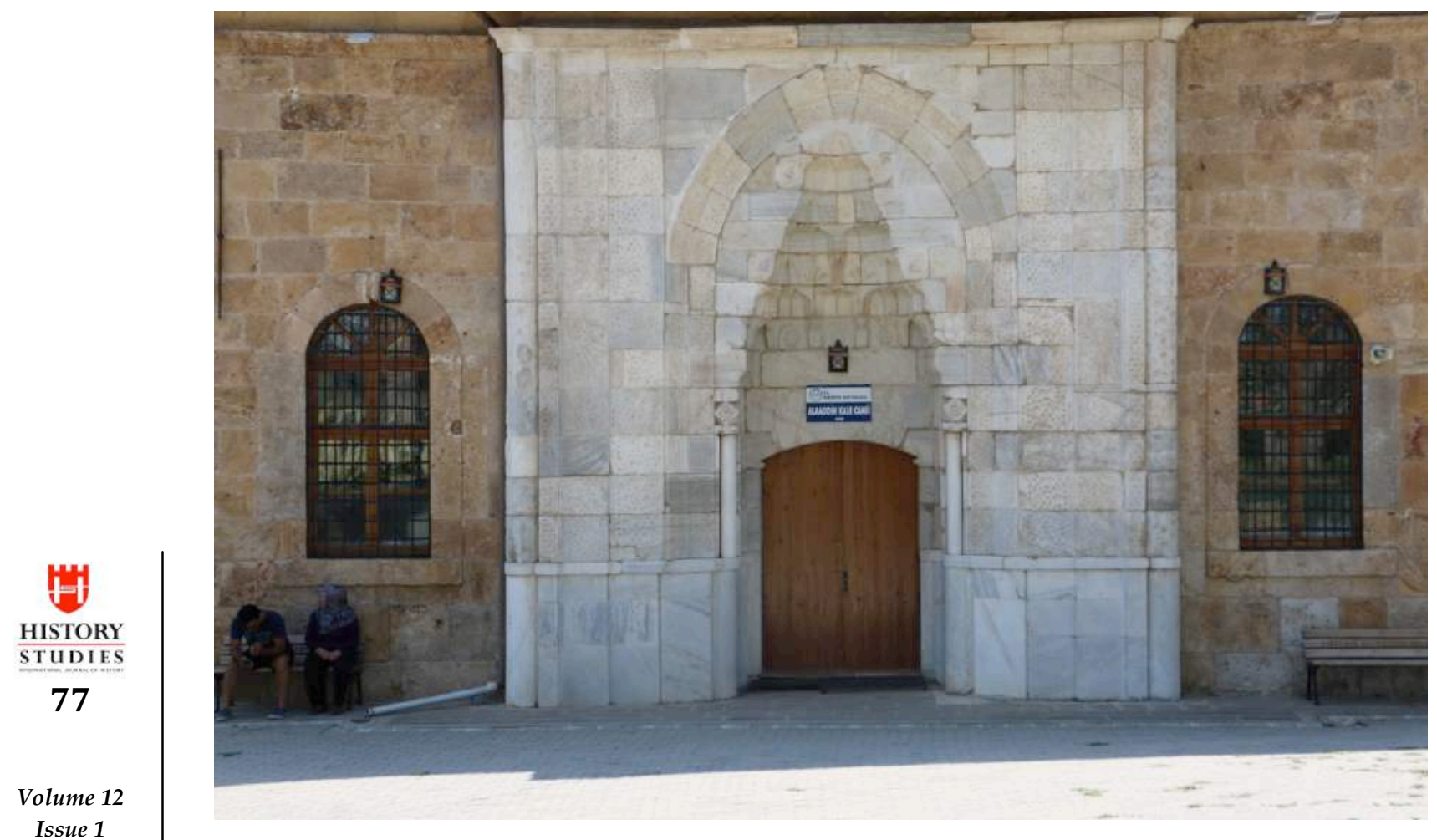

Fotoğraf 11: Melik Gazi Medresesi Taçkapı 
Kırşehir Melik Gazi Türbesi Üzerinden Yeni Bir Değerlendirme

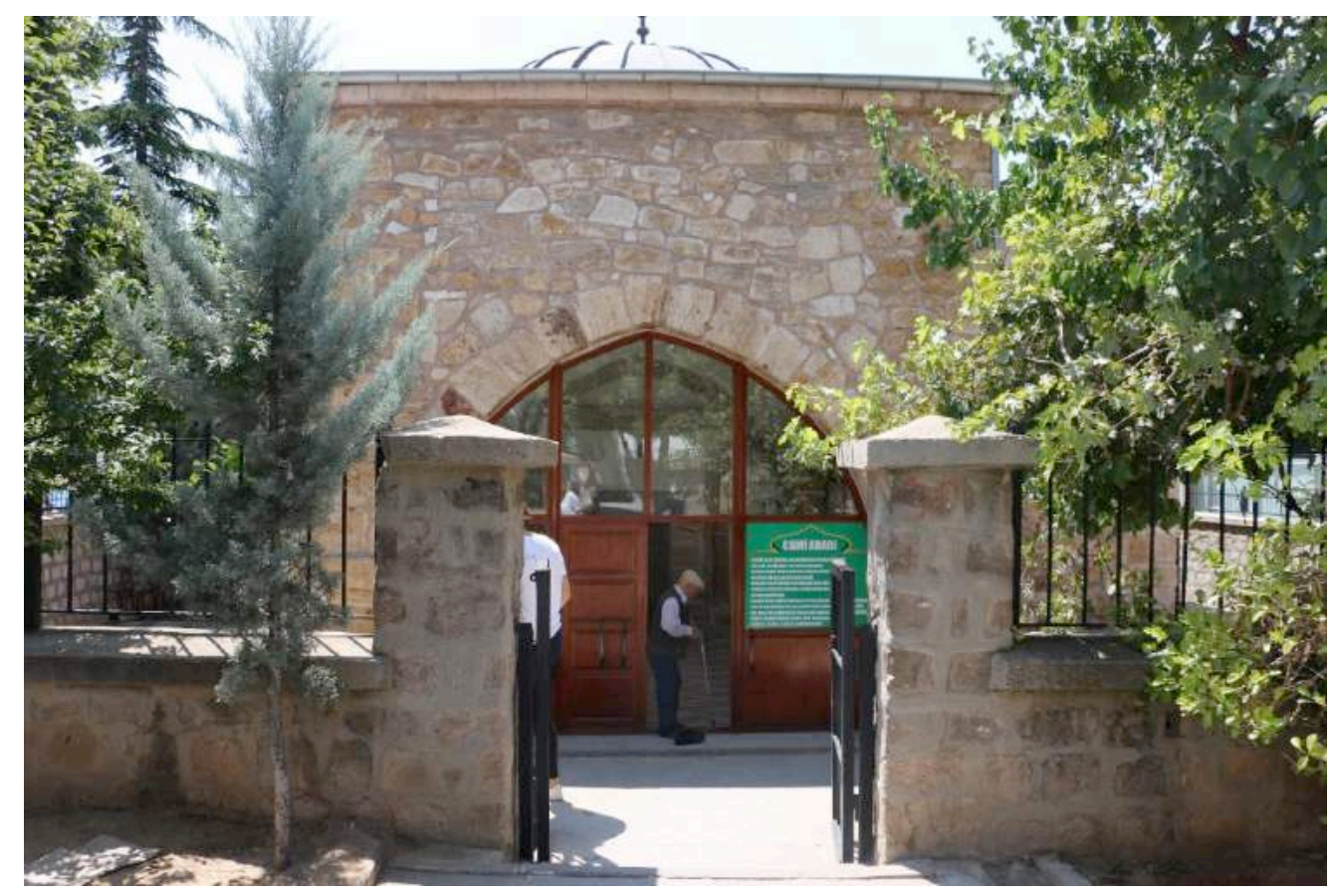

Fotoğraf 12: Türbenin güneyindeki Lale Cami

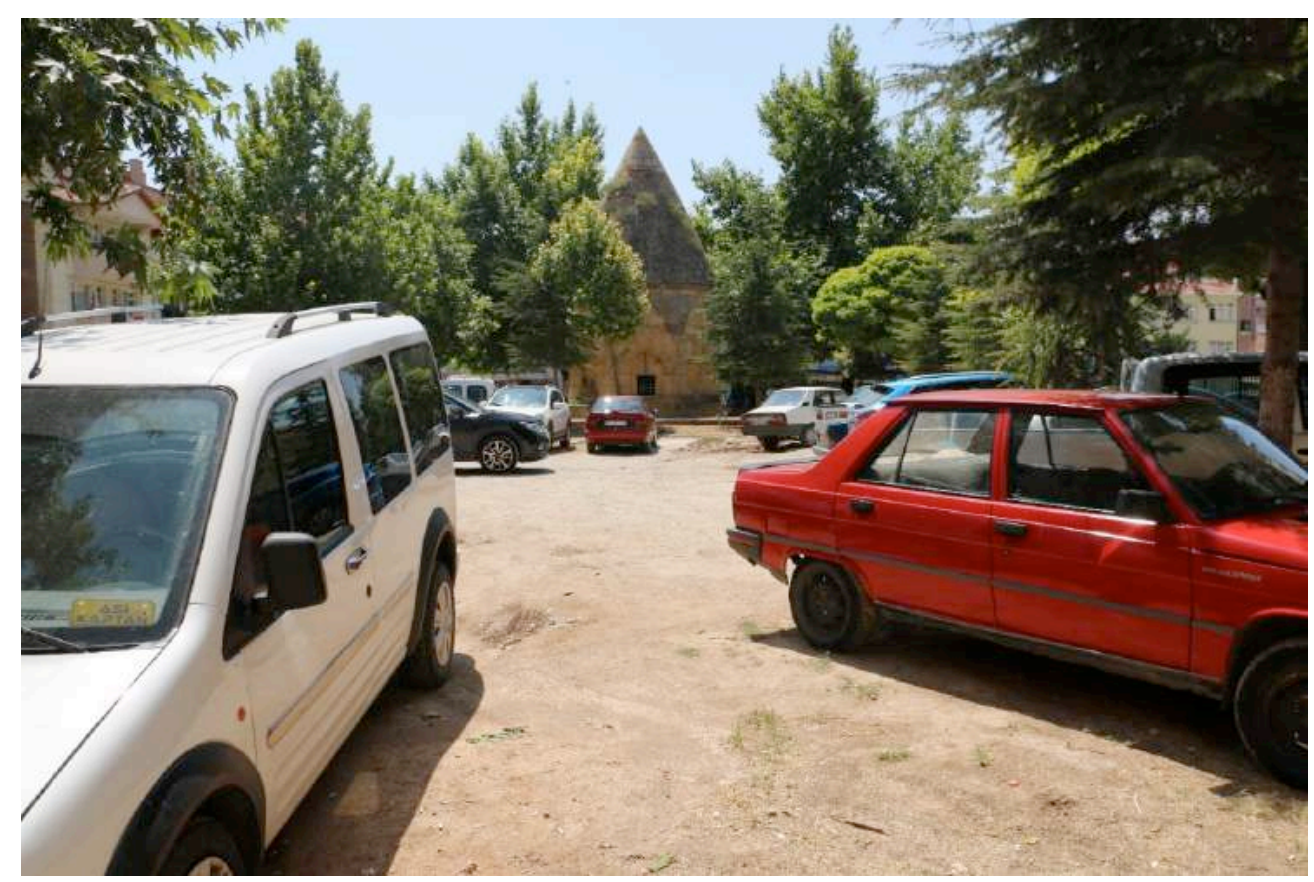

Fotoğraf 13: Lale Cami'den türbeye bakış 
Ayşegül Bekmez

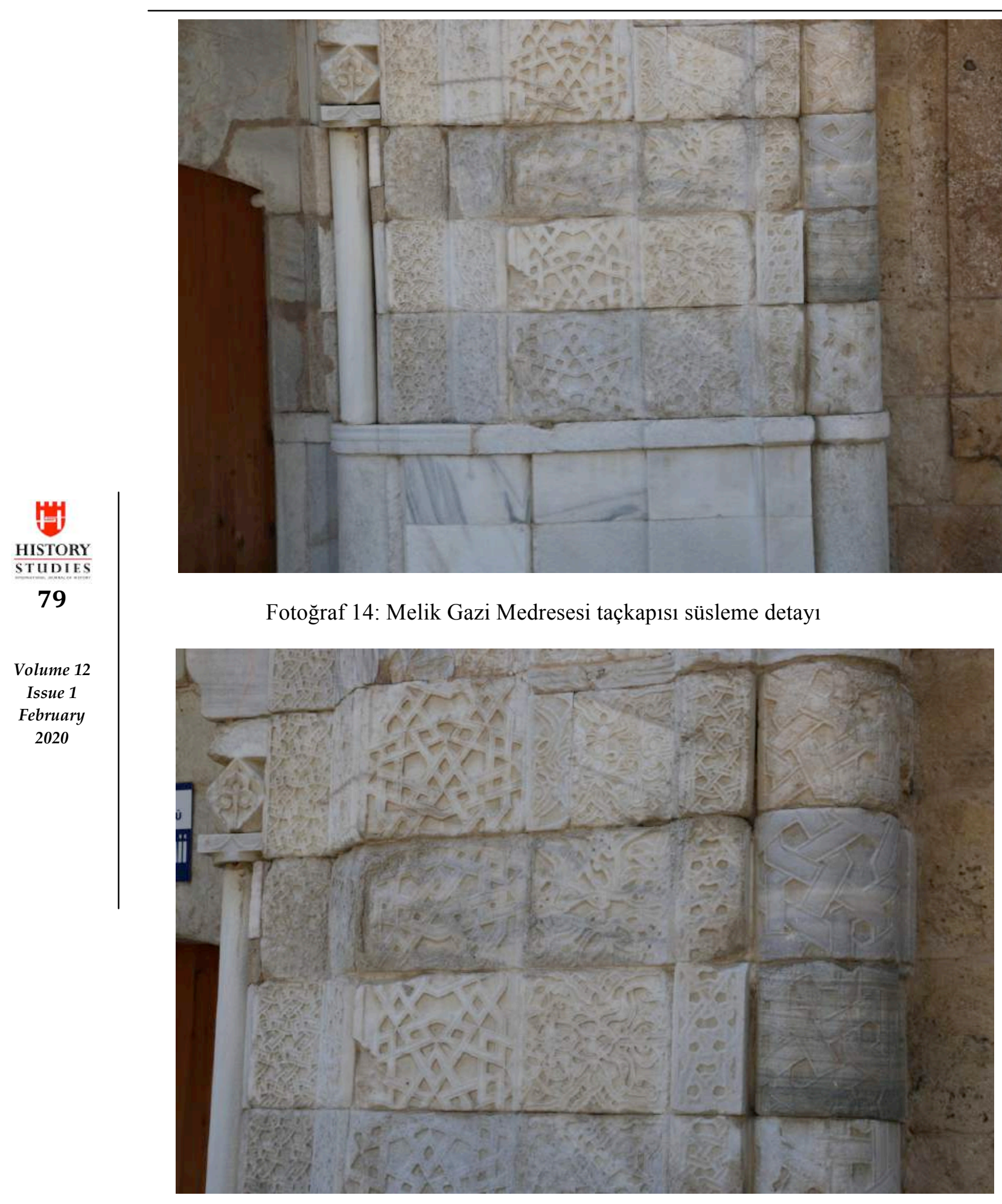

Fotoğraf 15: Melik Gazi Medresesi taçkapısı süsleme detay 


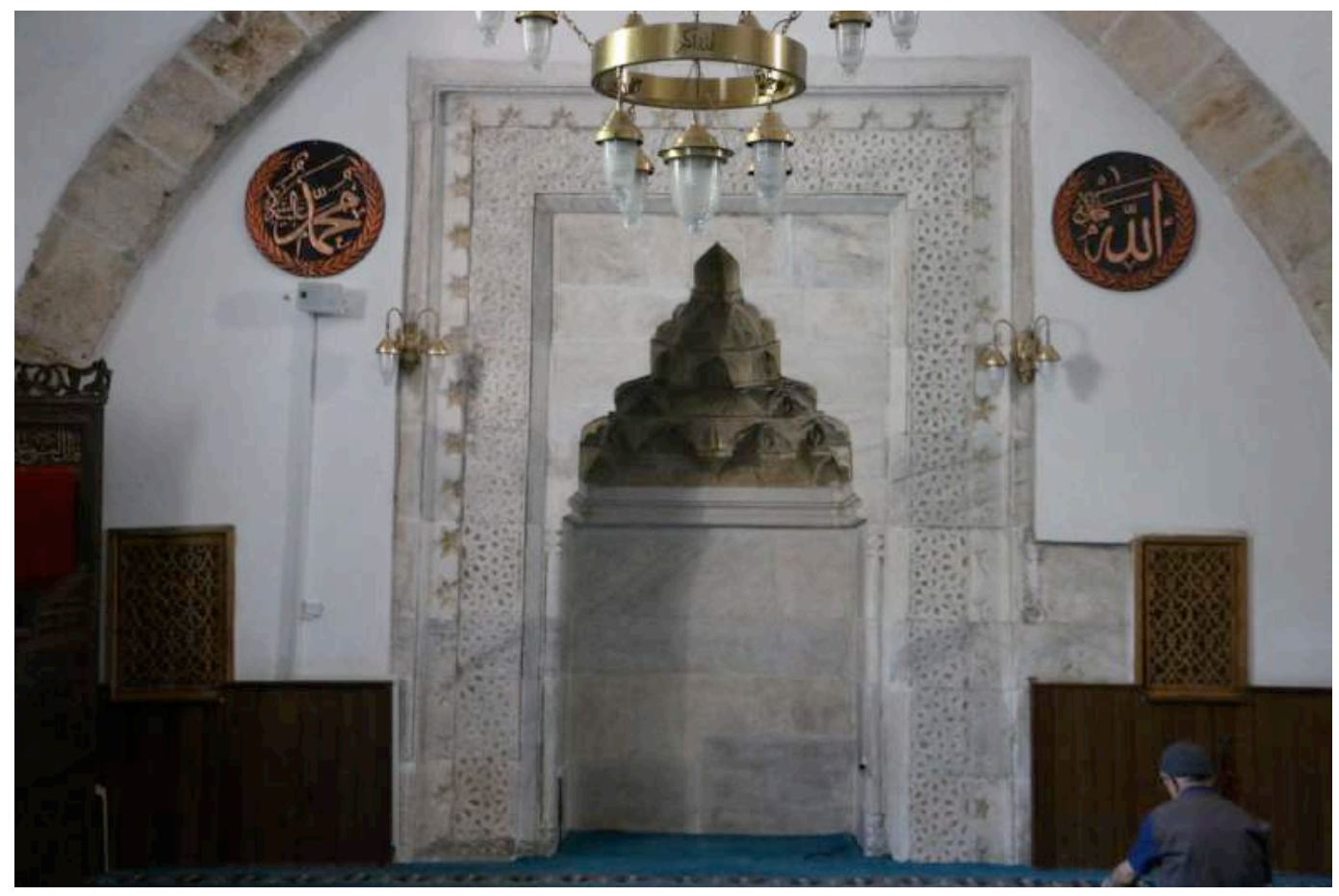

Fotoğraf 16: Lale Cami mihrabı

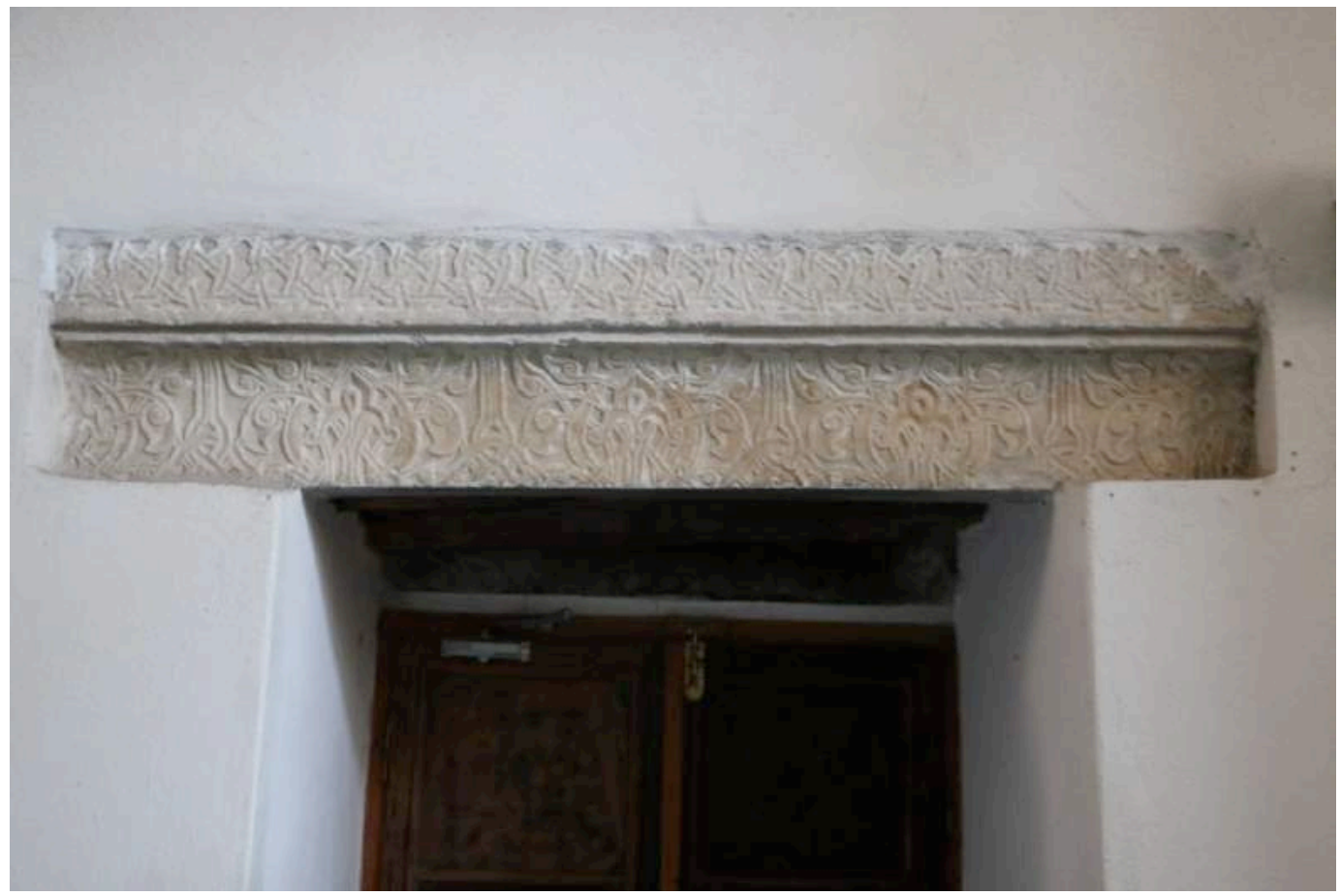

Volume 12

Issue 1

February

2020

Fotoğraf 17: Lale Cami harim girişi lento taşı 




Fotoğraf 18: Melik Gazi Türbesi taçkapı süsleme detayı

Volume 12

Issue 1

February 2020

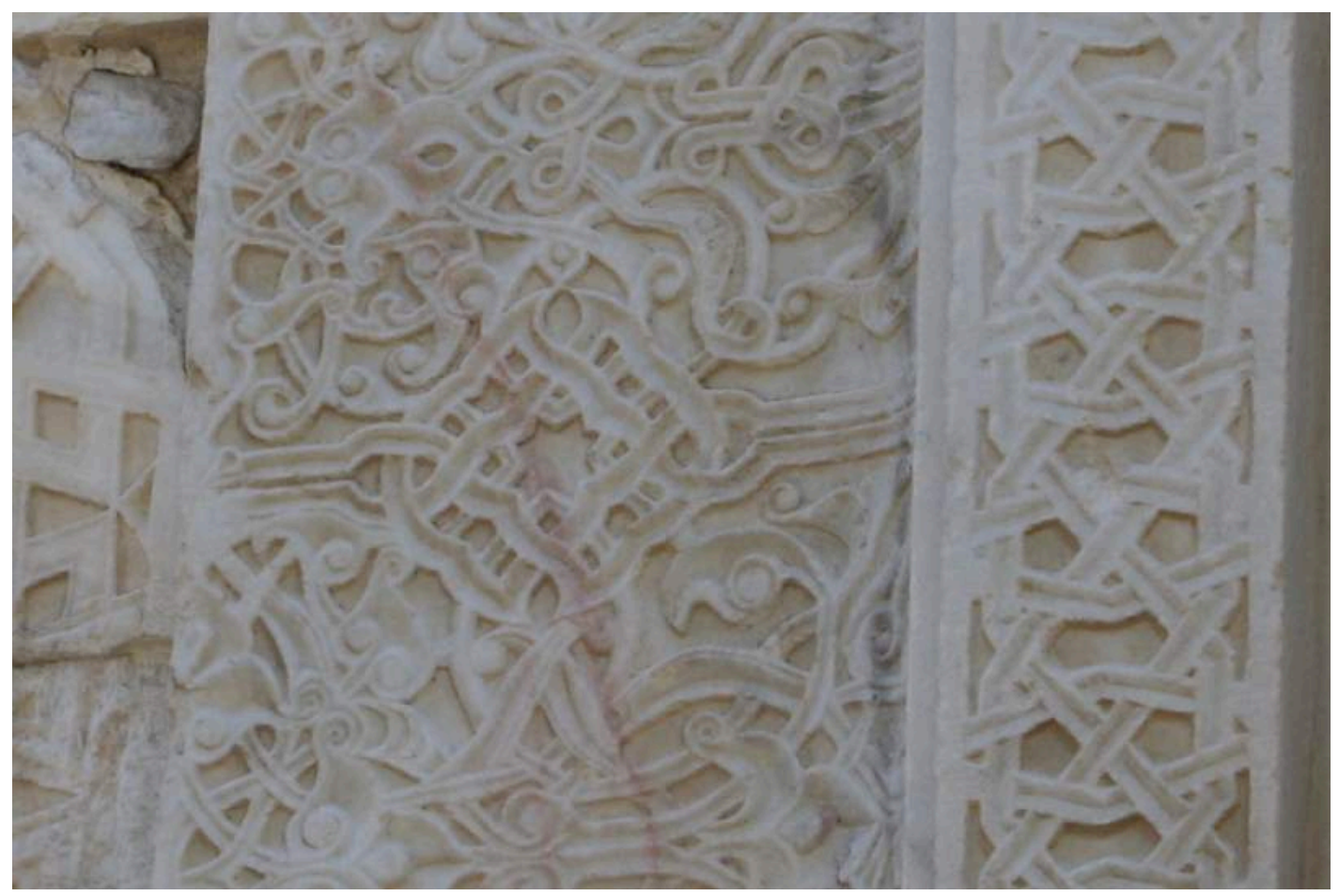

Fotoğraf 19: Melik Gazi Medresesi taçkapı süsleme detay1 


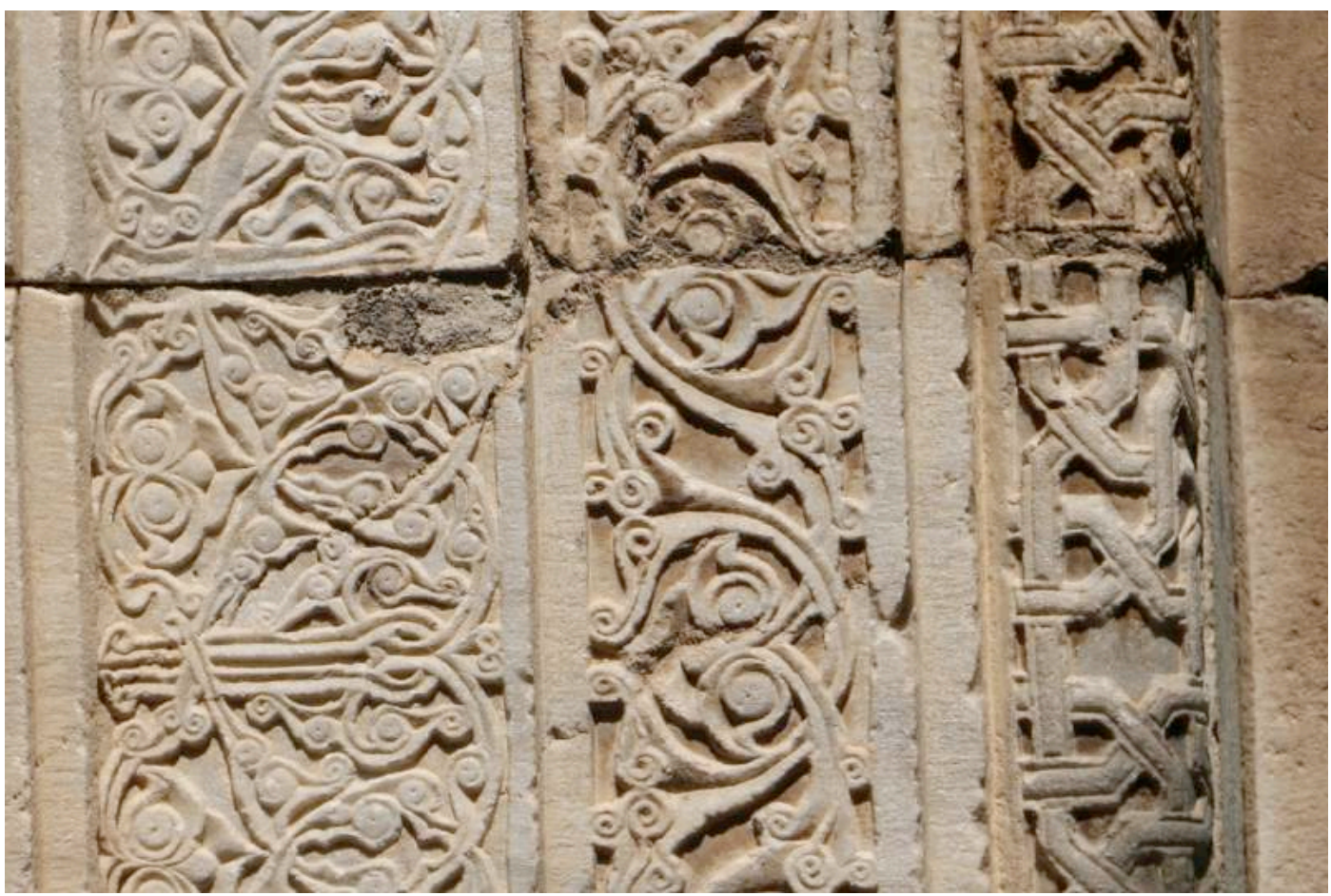

Fotoğraf 20: Melik Gazi Türbesi taçkapı süsleme detay1

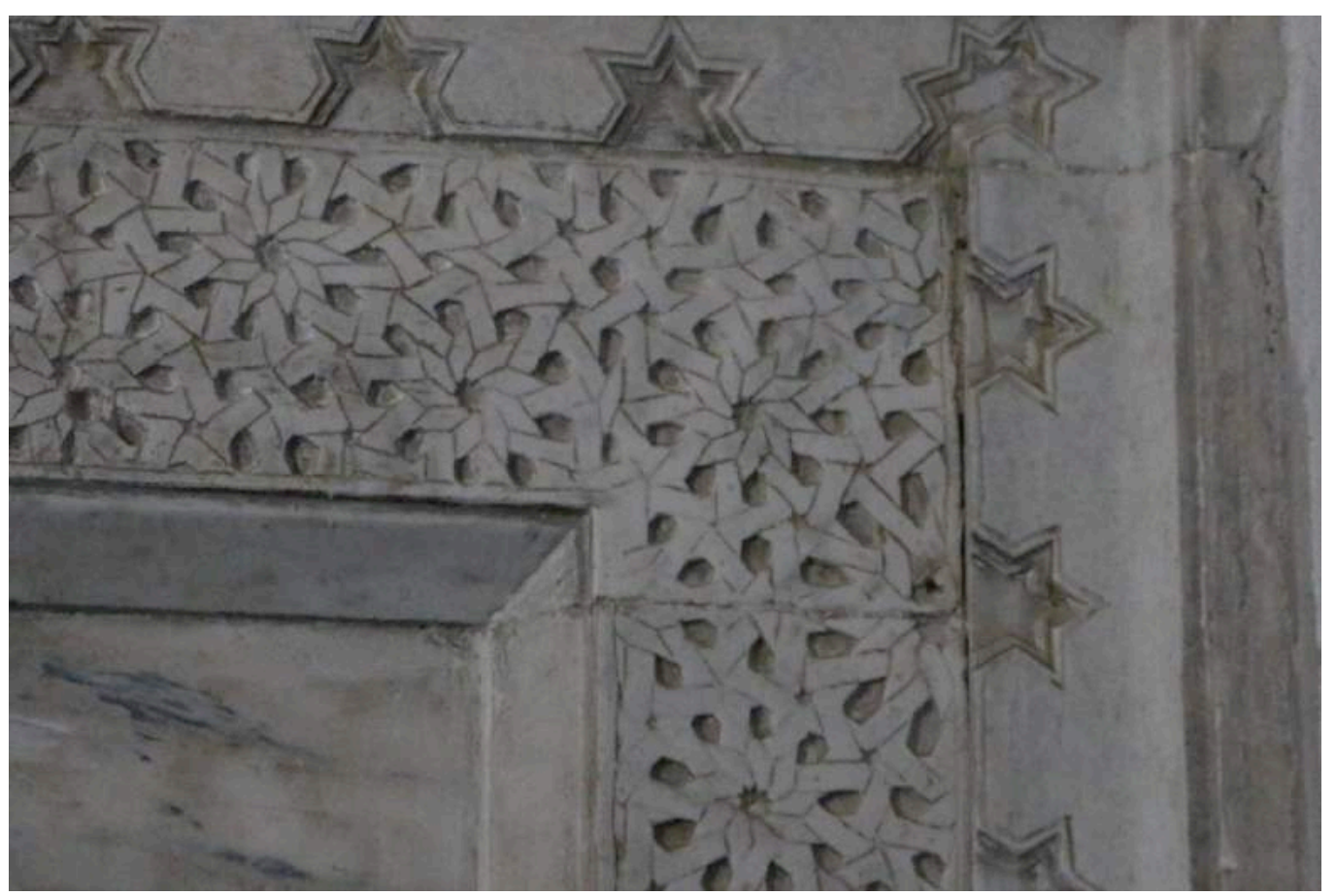

Volume 12

Issue 1

February 2020

Fotoğraf 21: Lale Cami mihrabı süsleme detay1 


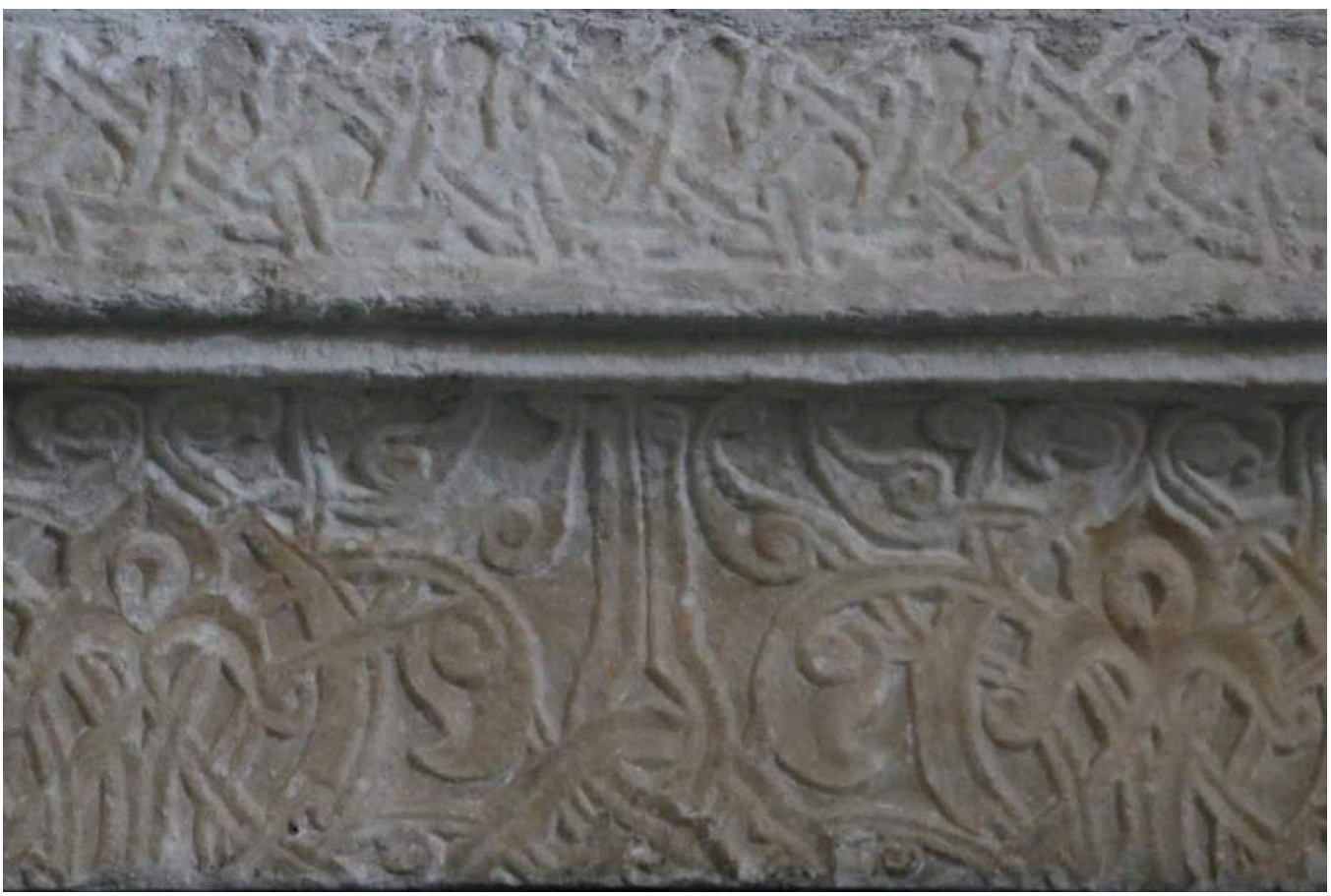

Fotoğraf 22: Lale Cami lento taşı süsleme detayı

Volume 12

Issue 1

February

2020

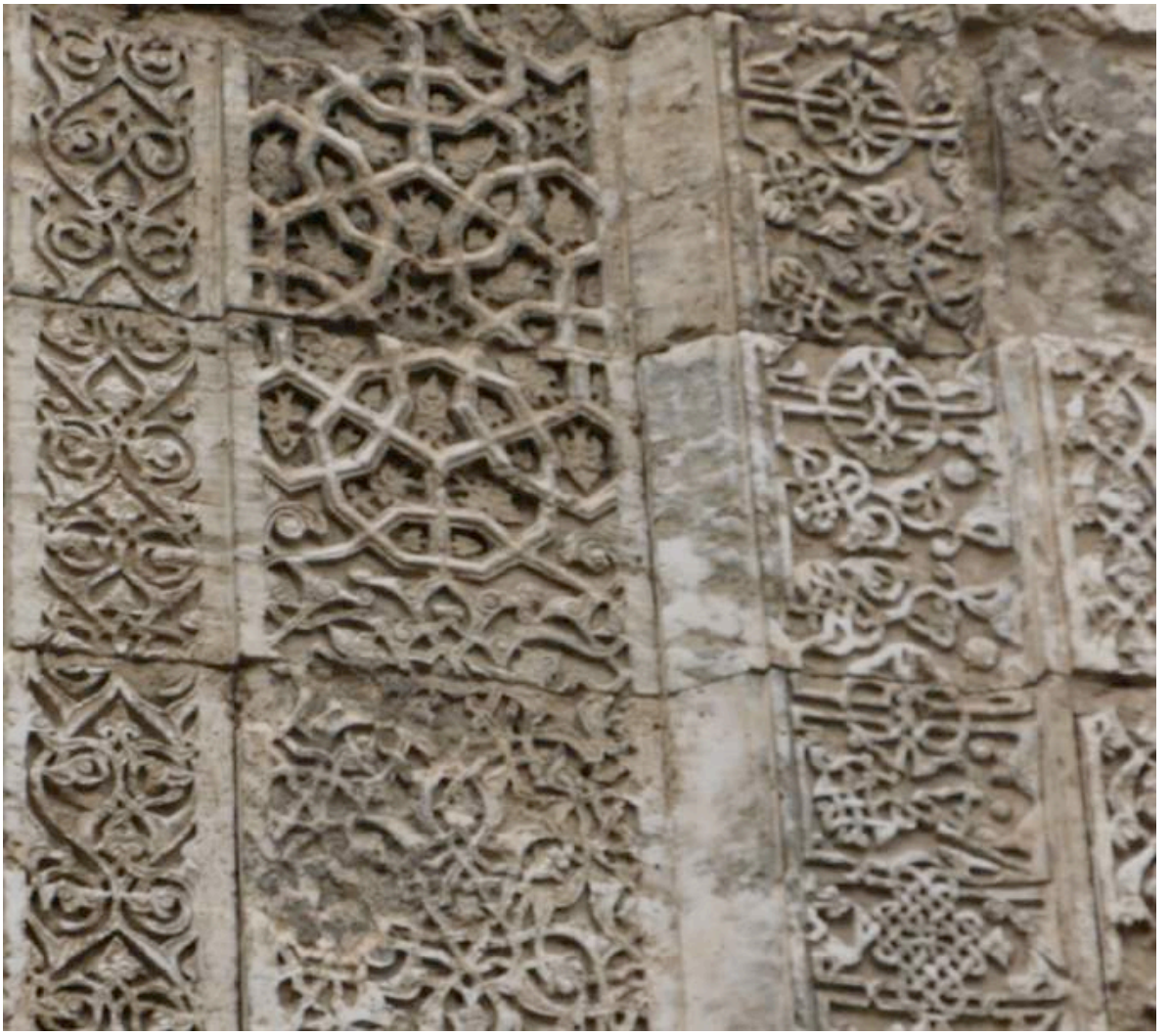

Fotoğraf 23: Sivas Çifte Minareli Medrese süsleme detay1

\section{History Studies}




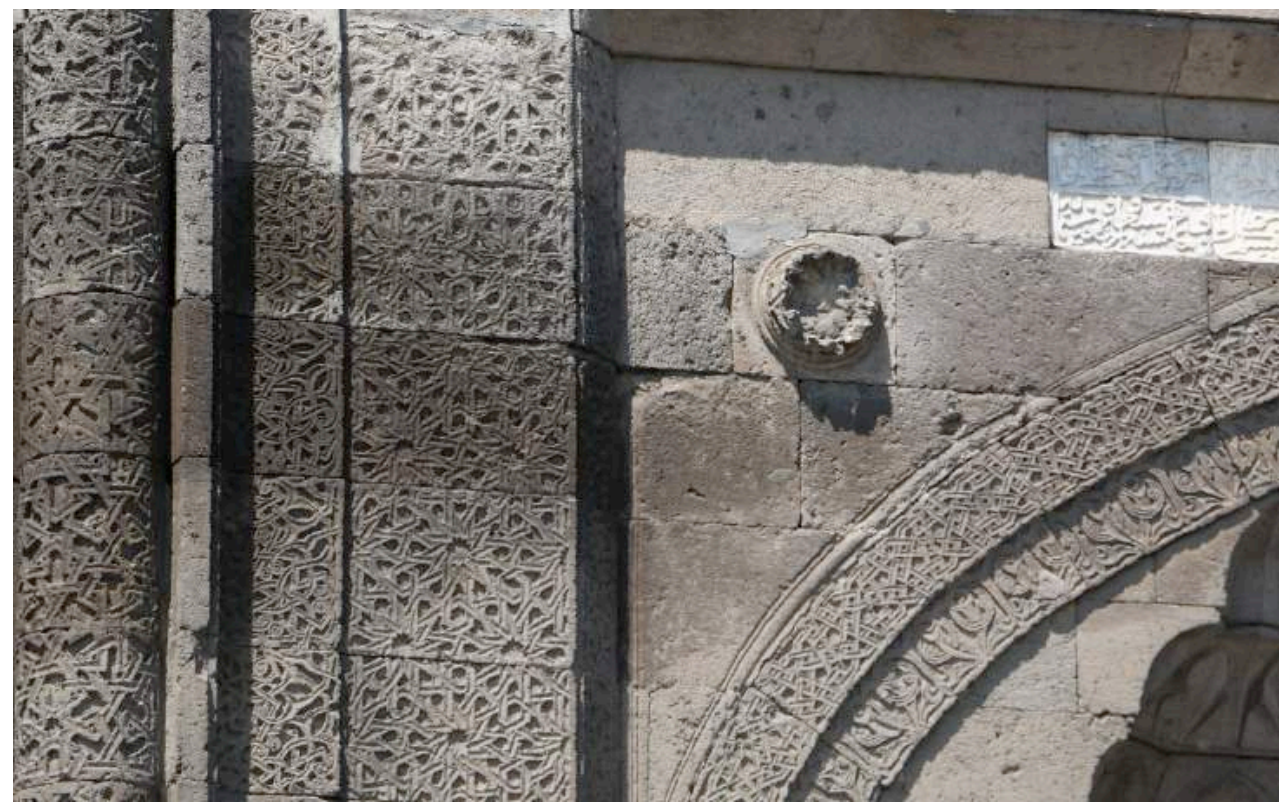

Fotoğraf 24: Kayseri Hacı Kılıç Cami doğu taçkapısı süsleme detayı

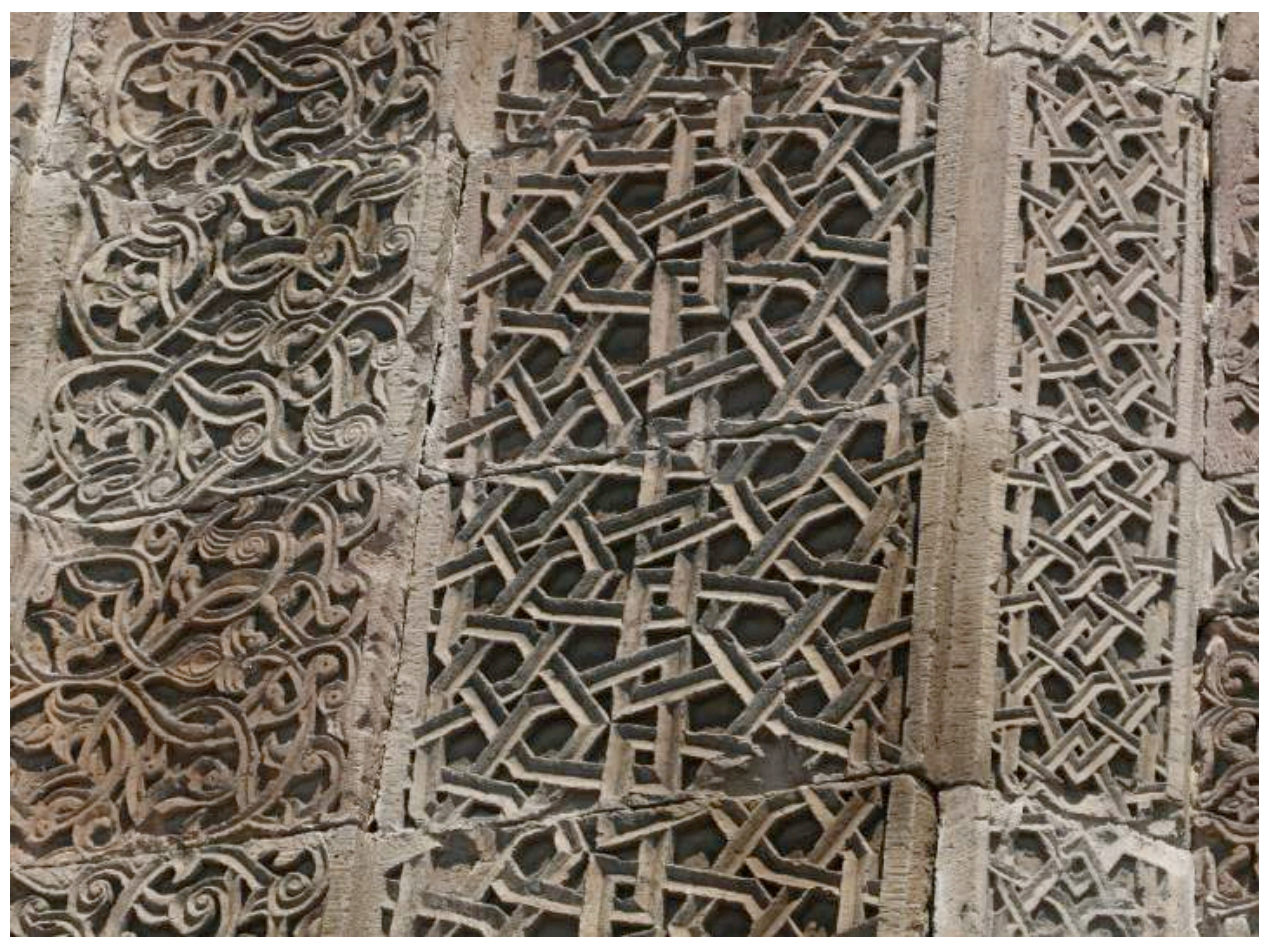

Fotoğraf 25: Kayseri Sahip Ata Medresesi taçkapı süsleme detayı 


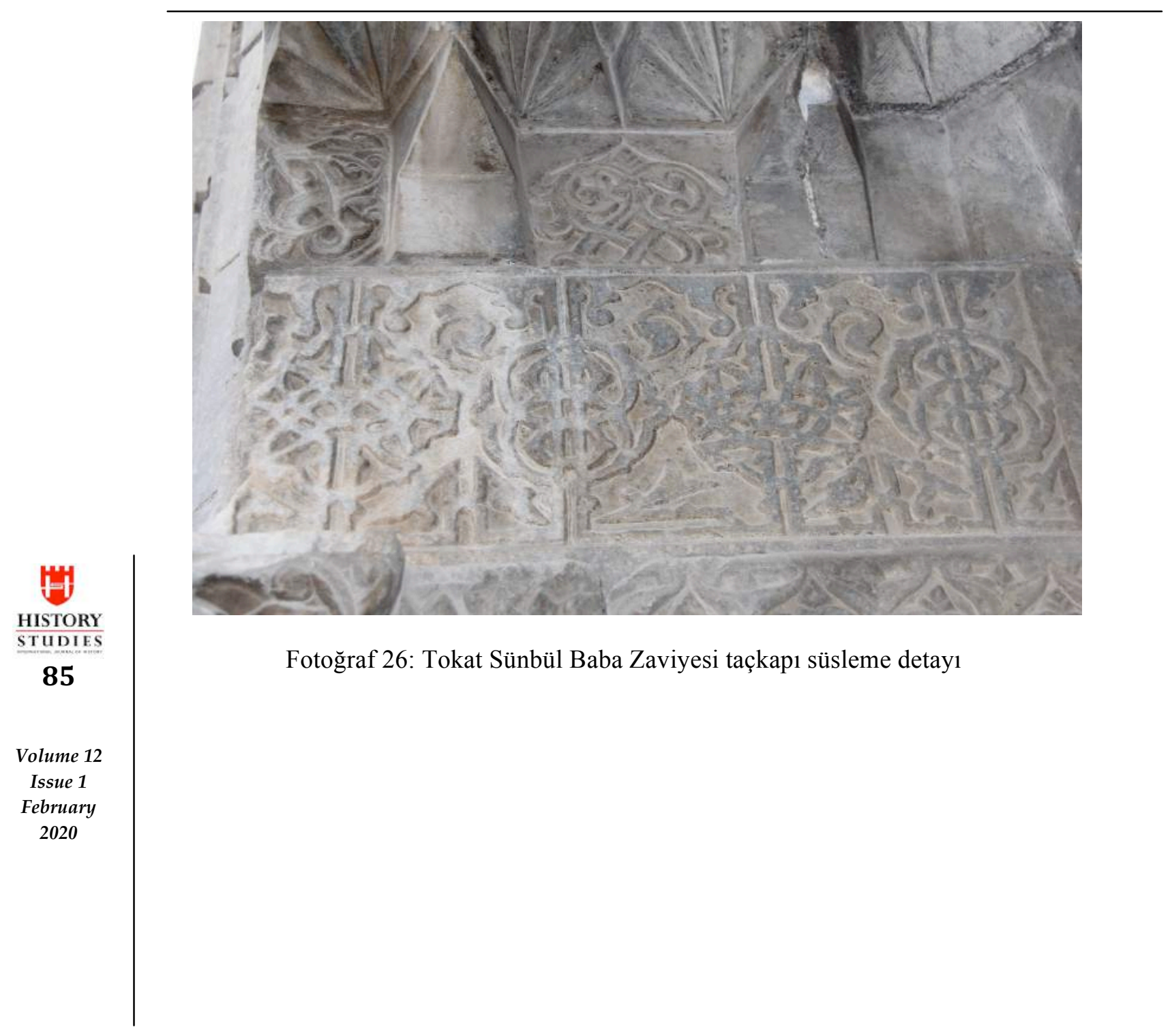

